\title{
OPEN Growth, ionic homeostasis, and physiological responses of cotton under different salt and alkali stresses
}

\author{
Huijuan Guo, Zhijie Huang, Meiqi Li \& Zhenan Hou ${ }^{\bowtie}$
}

To better understand the mechanism of salt tolerance, we analyzed cotton growth and the ionomes in different tissues under different types of salt-alkali stress. Cotton was exposed to the soil salt and alkali stresses, $\mathrm{NaCl}, \mathrm{Na}_{2} \mathrm{SO}_{4}$, and $\mathrm{Na}_{2} \mathrm{CO}_{3}+\mathrm{NaHCO}_{3}$, in a pot study. Salt and alkali stress significantly inhibited cotton growth, significantly reduced root length, surface area, and volume, and significantly increased relative electrical conductivity (REC) and malondialdehyde (MDA) content but also significantly increased antioxidant enzyme activities, and proline (Pro) content. The REC in leaves was higher under salt stress than under alkali stress, but the effects on Pro were in the order $\mathrm{Na}_{2} \mathrm{CO}_{3}+\mathrm{NaHCO}_{3}>\mathrm{NaCl}>\mathrm{Na}_{2} \mathrm{SO}_{4}$. Principal component analysis showed a significant difference in ion composition under the different types of salt-alkali stress. Under the three types of salt-alkali stress, concentrations of $\mathrm{Na}$ and $\mathrm{Mo}$ increased significantly in different organs of cotton plants. Under $\mathrm{NaCl}$ stress, the absorption of Ca was inhibited, the transport capacity of $\mathrm{P}, \mathrm{Mg}$, and Cu was reduced, and the ion balance was maintained by promoting the uptake and transport of $\mathrm{Zn}, \mathrm{Mn}, \mathrm{Al}$, and Mo. Under $\mathrm{Na}_{2} \mathrm{SO}_{4}$ stress, the absorption of $\mathrm{P}$ and $\mathrm{Ca}$ was inhibited, the transport capacity of $\mathrm{Mg}$, $\mathrm{B}$, and Cu was reduced, and the ion balance was maintained by promoting the uptake and transport of $S$, $\mathrm{Zn}, \mathrm{Fe}, \mathrm{Mo}, \mathrm{Al}$, and $\mathrm{Co}$. Under $\mathrm{Na}_{2} \mathrm{CO}_{3}+\mathrm{NaHCO}_{3}$ stress, the absorption of $\mathrm{P}$ and $\mathrm{S}$ was inhibited, the transport capacity of $\mathrm{Mg}$ and $\mathrm{B}$ was reduced, but that of $\mathrm{Al}$ and Fe increased, and the ion balance was maintained by promoting the uptake and transport of $\mathrm{Mn}, \mathrm{Mo}, \mathrm{Ni}$, and $\mathrm{Co}$. The relative expression of GhSOS1 and GhNHX1 in leaves increased significantly under salt stress but decreased under alkali stress. These results suggest that cotton is well-adapted to salt-alkali stress via the antioxidant enzyme system, adjustment of osmotic substances, and reconstruction of ionic equilibrium; neutral salt stress primarily disrupts the ion balance, whereas alkali stress decreases the ability to regulate $\mathrm{Na}$ and inhibits the absorption of mineral elements, as well as disrupts the ion balance; and the changes in the expression of salt tolerance-related genes may partially explain the accumulation of $\mathrm{Na}$ ions in cotton under salt-alkali stress.

Soil salinization is a global ecological problem that threatens the environment and the development of sustainable agriculture ${ }^{1}$. Cotton is a "pioneer crop" used to develop and use salt-alkali soil and is also a model plant used to study the mechanism of salt tolerance because of its relatively high salt tolerance. However, salt-alkali stress still greatly affects cotton growth ${ }^{2}$. With the increasing change in the global climate and the worsening of soil salinization, it is urgent that we improve salt tolerance in plants ${ }^{3}$. There are different types of soil salinization, with neutral and alkaline salts causing two distinct types of salt stress, to which crops have different responses and salt-tolerance mechanisms ${ }^{4}$. Salt stress occurs with neutral salts $\left(\mathrm{NaCl}\right.$ and $\left.\mathrm{Na}_{2} \mathrm{SO}_{4}\right)$, with osmotic stress and ion toxicity the main effects on plants ${ }^{5}$. Alkali stress occurs with alkaline salts $\left(\mathrm{NaHCO}_{3} \text { and } \mathrm{Na}_{2} \mathrm{CO}_{3}\right)^{6}$, mainly because the high $\mathrm{pH}$ affects plant growth and disrupts the ion balance ${ }^{7}$. The risk of salt-alkali stress may be greater than that of neutral salt stress ${ }^{8}$. However, few studies have examined the effects of different types of salt stress, even though our understanding of the salt-tolerance mechanisms of crops under different salt-alkali stresses needs to be improved ${ }^{9,10}$.

The salt-tolerance mechanism of cotton has been widely studied. Under salt-alkali stress, the morphological index and root development during cotton growth can most intuitively reflect the stress status of cotton. 
According to Wang et al. ${ }^{11}$ and Chachar et al. ${ }^{12}$, cotton growth is significantly inhibited, seedling biomass is significantly reduced, and root development is inhibited under salt-alkali stress. Furthermore, salt-alkali stress causes ion toxicity in plants, as a result of imbalances disrupting ion homeostasis. The reconstruction of ion homeostasis under salt-alkali stress is one important mechanism by which plants improve their salt-alkali tolerance ${ }^{13}$. Ionomics is a new approach to study the response of plants to salt-alkali stress, and the mineral nutrient and trace element ionome of plants can be used to characterize the inorganic components of cells and biological systems ${ }^{14}$. Mineral elements guarantee the growth of $\mathrm{crops}^{15}$. However, primarily because excess salt ions in soil cause competition among ions for absorption in cotton under salt-alkali stress, the absorption and transport of mineral elements are substantially affected, resulting in mineral nutrient stress and imbalance in crop ion homeostasis. Salt stress not only inhibits the uptake of macro elements (N, P, K, Ca, Mg, S) by crops but also limits the absorption of trace elements ( $\mathrm{Fe}, \mathrm{Cu}, \mathrm{Zn}, \mathrm{Mn}$, and $\mathrm{B}$, among others ${ }^{16}$. In addition to being nutrients for crop growth, these mineral elements also participate in various physiological metabolic processes that directly or indirectly affect the salt tolerance of crops.

Although each element has a unique physiological function in crop growth, the primary function of each is to maintain intracellular ionic homeostasis. Maintaining intracellular ionic homeostasis is an important mechanism by which crops adapt to salt stress, and all the physiological activities related to salt tolerance in crops are aimed at maintaining ionic homeostasis. Therefore, to reveal the mechanism of salt tolerance in crops, it is important to examine the mechanisms that maintain ionic homeostasis during the absorption of mineral nutrients by plants under salt stress. The absorption of ions by cotton under salt stress and the use of mineral elements to improve the salt tolerance of cotton have been investigated ${ }^{17,18}$. However, the focus of most previous studies has been on the effects of salt stress on one or more mineral elements, and the responses of other elements and their interactions with salt stress have not been fully elucidated ${ }^{16}$. Therefore, our understanding of the relationship between the mechanism of salt-tolerance and the ionome remains fragmented and incomplete.

Environmental factors can also influence ion homeostasis by regulating associated genes. Two key salttolerance genes are SOS1 and NHX1 $1^{19,20}$. The SOS pathway is involved in the maintenance of ionic homeostasis, and $\mathrm{NHX} 1$ participates in $\mathrm{Na}^{+}$transport and compartmentalization, maintains osmotic balance, and reduces cytosolic $\mathrm{Na}^{+}$concentration ${ }^{21}$. Therefore, the analysis of the expression of $\mathrm{Na}^{+}$transport-related genes can help to explain the changes in ion homeostasis and reveal the salt-tolerance mechanism in cotton under salt-alkali stress.

The salt tolerance of crops involves a variety of defense mechanisms, including maintaining ionic homeostasis and osmotic equilibrium and scavenging reactive oxygen species (ROS) ${ }^{22,23}$. In ionomics, high-throughput analysis (ICP-MS) is used to quantitatively study the ionome characteristics of an organism, providing an important approach to understand the element-element and element-environment interactions as well as the physiological and biochemical functions of elements ${ }^{24}$. Because salt-alkali stress is one of the most serious abiotic stress factors limiting crop production, an in-depth understanding of the responses of ionomes under salt-alkali stress remains essential to understand the mechanism of ionic homeostasis in cotton. In addition, as understanding increases, we can provide a theoretical basis to improve the salinity and alkalinity tolerance of cotton by ionic regulation and rational fertilization in salt-alkali soil, as well as provide a reference for the breeding of salttolerant cotton cultivars.

In this study, we examined the effects of different types of salt-alkali stress on (1) the biomass of cotton plants and the morphological characters of root length, surface area, and volume; (2) the physiological indices of salt tolerance (REC, MDA, Pro), the biochemical indices (activities of superoxide dismutase (SOD), peroxidase (POD), catalase (CAT)), and the mechanisms of organic osmotic regulation and enzyme protection; (3) the ionomic responses and distributions of the main mineral elements in cotton plants, as well as the correlations between $\mathrm{Na}$ and other elements; and (4) the expression of $\mathrm{Na}^{+}$transport-related genes involved in ionic homeostasis in cotton.

\section{Results}

Changes in cotton biomass and root morphology after salt and alkali stresses. Cotton biomass decreased significantly under salt-alkali stress (Fig. 1). Compared with the CK, total cotton biomass decreased by $57.55 \%$ in the CS treatment, by $49.19 \%$ in the SS treatment, and by $58.61 \%$ in the AS treatment. Compared with the CK, the biomass of the root, stem, and leaves was significantly lower by $47.98 \%, 65.64 \%$, and $32.07 \%$, respectively, in the CS treatment (Fig. 1a), by $46.86 \%, 51.17 \%$, and $43.18 \%$, respectively, in the SS treatment (Fig. 1b), and by 59.93\%, 57.50\%, and 31.17\%, respectively, in the AS treatment (Fig. 1c).

Salt-alkali stress significantly decreased root length, surface area, and volume (Fig. 2). Compared with the $\mathrm{CK}$, root length, surface area, and volume decreased significantly by $44.33 \%, 25.62 \%$, and $10.80 \%$, respectively, in the CS treatment, by $40.53 \%, 38.49 \%$, and $38.40 \%$, respectively, in the SS treatment; and by $23.63 \%, 20.85 \%$, and $25.28 \%$, respectively, in the AS treatment.

Changes in cotton physiological response after salt and alkali stresses. The MDA content and REC of leaves increased significantly under salt-alkali stress (Fig. 3). Compared with the CK, the MDA content in the leaves increased significantly by $211.72 \%$ in the CS treatment, by $114.48 \%$ in the SS treatment, and by $208.28 \%$ in the AS treatment. Similarly, compared with the CK, the REC in leaves increased significantly by $74.06 \%$ in the CS treatment, by $99.83 \%$ in the SS treatment, and by $31.54 \%$ in the AS treatment.

Salt-alkali stress significantly increased the activities of SOD, POD, and CAT in leaves (Fig. 4). Compared with the CK, the SOD activity increased significantly by $118.89 \%$ in the CS treatment, by $159.92 \%$ in the SS treatment, and by $215.29 \%$ in the AS treatment; the POD activity increased significantly by $8.98 \%$ in the CS treatment, by $16.80 \%$ in the SS treatment, and by $12.38 \%$ in the AS treatment; and the CAT activity increased significantly by $139.78 \%$ in the CS treatment, by $116.70 \%$ in the SS treatment, and by $275.91 \%$ in the AS treatment. 


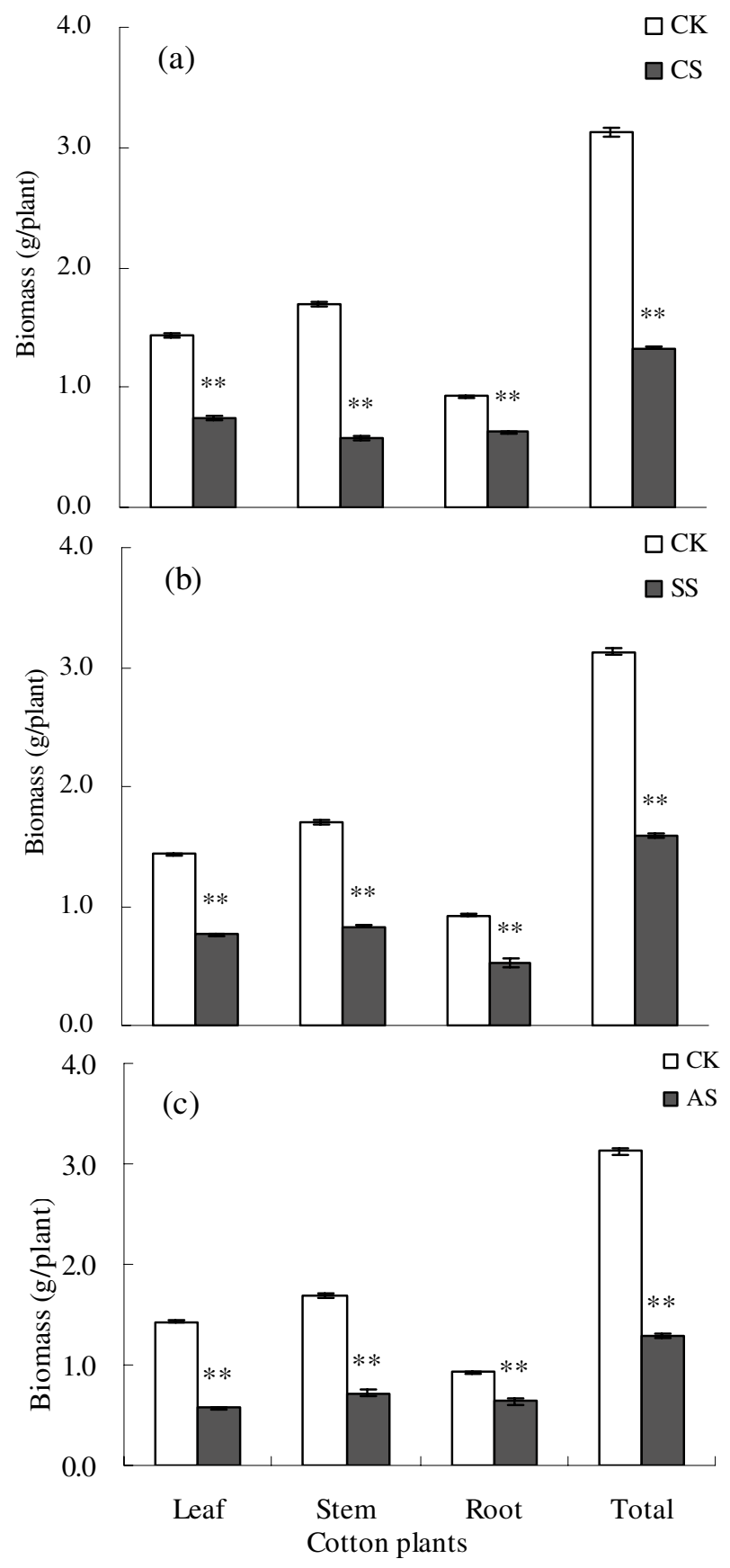

Figure 1. Leaf, stem, root, and total biomass (g/plant) of cotton plants under different types of salt-alkali stress: (a) $\mathrm{NaCl}$ (CS), (b) $\mathrm{Na}_{2} \mathrm{SO}_{4}$ (SS), and (c) $\mathrm{Na}_{2} \mathrm{CO}_{3}+\mathrm{NaHCO}_{3}$ (AS). Columns with bars represent the mean \pm standard error $(n=3)$. Asterisks indicate a significant difference between the control $(\mathrm{CK})$ and the saltalkali stress $\left({ }^{* *} p<0.01\right)$.

Salt-alkali stress significantly increased the Pro content in cotton leaves (Fig. 5). Compared with the CK, the proline content in the leaves increased significantly by $230.07 \%$ in the CS treatment, by $77.91 \%$ in the SS treatment, and by $264.19 \%$ in the AS treatment.

Changes in cotton tissue ionomes after salt and alkali stresses. To demonstrate the effect of saltalkali stress on element distribution in cotton, we analyzed the concentrations of the ions $\mathrm{Na}, \mathrm{P}, \mathrm{K}, \mathrm{Ca}, \mathrm{Mg}, \mathrm{S}$, $\mathrm{Fe}, \mathrm{Mn}, \mathrm{Zn}, \mathrm{Cu}, \mathrm{B}, \mathrm{Mo}, \mathrm{Ni}, \mathrm{Co}, \mathrm{Al}, \mathrm{Si}$, and $\mathrm{Se}$ in the leaf, stem, and root under different types of salt-alkali stress. In the PCAs, the leaf (Fig. 6a), stem (Fig. 6b), and root (Fig. 6c) ionomes were separated on the basis of different types of salt-alkali stress. The different types of salt-alkali stress were well separated on the first principal component, accounting for $61.2 \%$ of the total variation in leaves, $42.3 \%$ of that in stems, and $41.4 \%$ of that in roots. The major elements that contributed to the PC1 were $\mathrm{Na}, \mathrm{Ca}, \mathrm{Mn}, \mathrm{Fe}, \mathrm{Mo}, \mathrm{Al}$, and Co in the leaf ionome; 


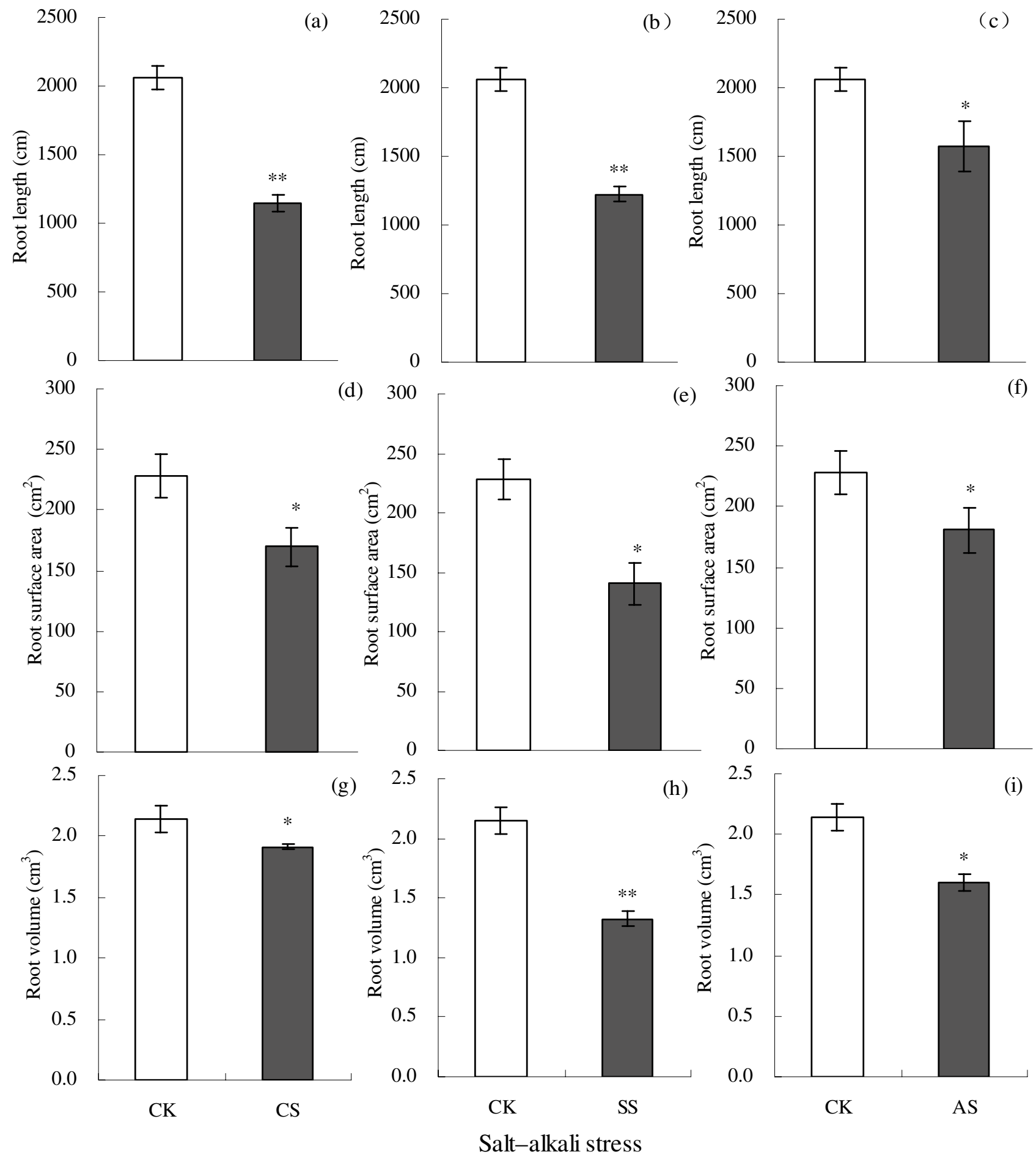

Figure 2. Root length $(\mathrm{cm})$, surface area $\left(\mathrm{cm}^{2}\right)$, and volume $\left(\mathrm{cm}^{3}\right)$ of cotton plants under different types of salt-alkali stress ( $\mathrm{NaCl}(\mathrm{CS}), \mathrm{Na}_{2} \mathrm{SO}_{4}(\mathrm{SS})$, and $\mathrm{Na}_{2} \mathrm{CO}_{3}+\mathrm{NaHCO}_{3}(\mathrm{AS})$ ). Columns with bars represent the mean \pm standard error $(n=3)$. Asterisks indicate a significant difference between the control $(\mathrm{CK})$ and the saltalkali stress $\left({ }^{*} p<0.05 ;{ }^{* *} p<0.01\right)$. (a-c) indicate the root length in $\mathrm{NaCl}, \mathrm{Na}_{2} \mathrm{SO}_{4}$, and $\mathrm{Na}_{2} \mathrm{CO}_{3}+\mathrm{NaHCO}_{3}$ stress, respectively. (d-f) indicate the surface area in $\mathrm{NaCl}, \mathrm{Na}_{2} \mathrm{SO}_{4}$, and $\mathrm{Na}_{2} \mathrm{CO}_{3}+\mathrm{NaHCO}_{3}$ stress, respectively. (g-i) indicate the root volume in $\mathrm{NaCl}, \mathrm{Na}_{2} \mathrm{SO}_{4}$, and $\mathrm{Na}_{2} \mathrm{CO}_{3}+\mathrm{NaHCO}_{3}$ stress, respectively.

$\mathrm{Na}, \mathrm{P}, \mathrm{Ca}, \mathrm{Cu}, \mathrm{Zn}$, and $\mathrm{Mo}$ in the stem ionome; and $\mathrm{Na}, \mathrm{P}, \mathrm{Mg}, \mathrm{Mn}, \mathrm{Mo}$, and $\mathrm{B}$ in the root ionome. Leaf and stem ionome analyses demonstrated that the SS treatment could be clearly distinguished from the other salt-alkali stress treatments using the second principal component, which explained $21.0 \%$ (leaf) and $25.0 \%$ (stem) of the 


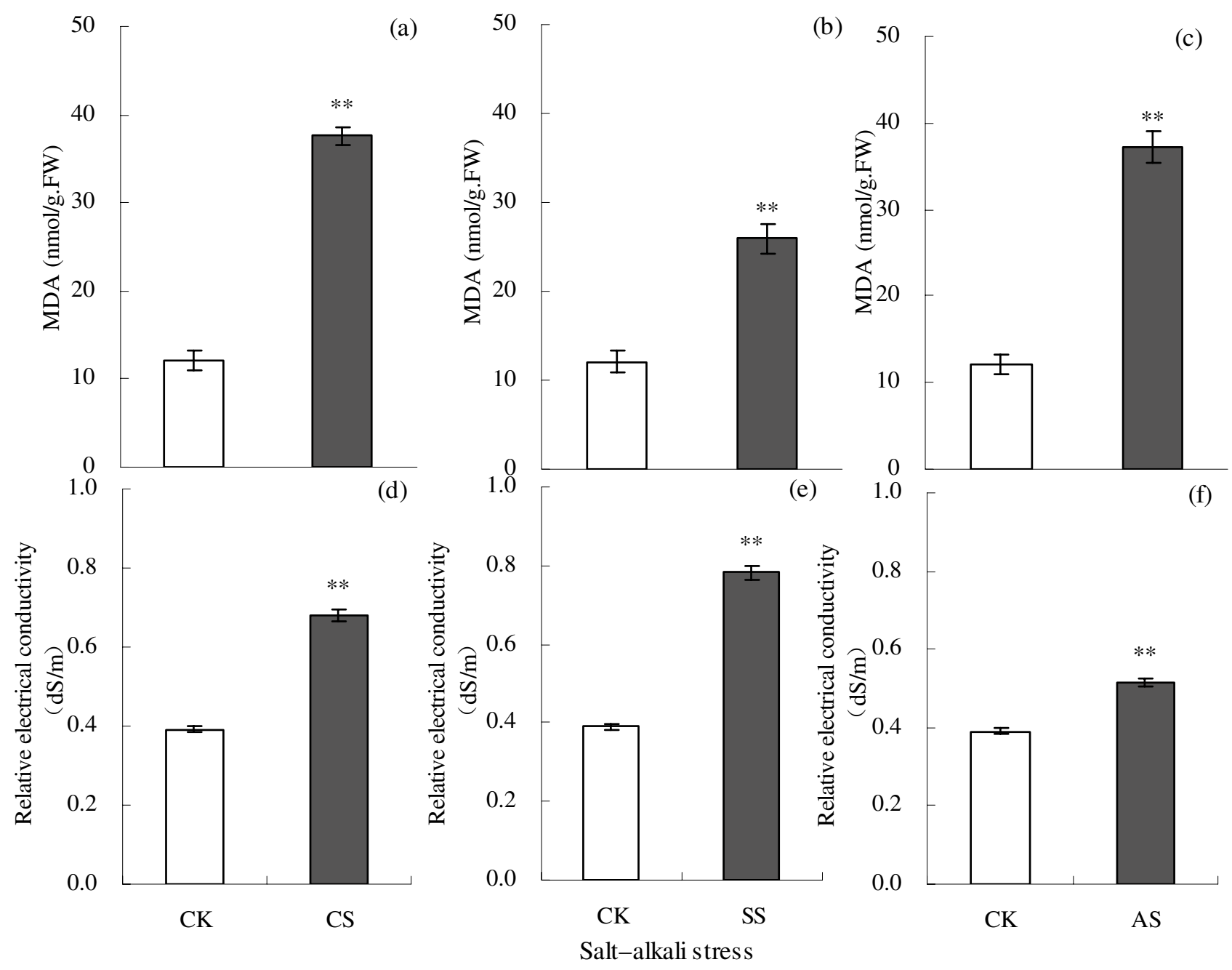

Figure 3. Malondialdehyde (MDA) content ( $\mathrm{nmol} / \mathrm{g}$ fresh weight $(\mathrm{FW})$ ) and relative electrical conductivity (REC) $(\mathrm{dS} / \mathrm{m})$ in cotton leaves under different types of salt-alkali stress $\left(\mathrm{NaCl}(\mathrm{CS}), \mathrm{Na}_{2} \mathrm{SO}_{4}(\mathrm{SS})\right.$, and $\left.\mathrm{Na}_{2} \mathrm{CO}_{3}+\mathrm{NaHCO}_{3}(\mathrm{AS})\right)$. Columns with bars represent the mean \pm standard error $(n=3)$. Asterisks indicate a significant difference between the control $(\mathrm{CK})$ and the salt-alkali stress $\left({ }^{* *} p<0.01\right)$. (a-c) indicate the MDA content in cotton leaves under $\mathrm{NaCl}, \mathrm{Na}_{2} \mathrm{SO}_{4}$, and $\mathrm{Na}_{2} \mathrm{CO}_{3}+\mathrm{NaHCO}_{3}$ stress, respectively. (d-f) indicate the REC in cotton leaves under $\mathrm{NaCl}, \mathrm{Na}_{2} \mathrm{SO}_{4}$, and $\mathrm{Na}_{2} \mathrm{CO}_{3}+\mathrm{NaHCO}_{3}$ stress, respectively.

total coefficient of variation. The contribution of elements to the PC2 was dominated by S and $\mathrm{Zn}$ in the leaf ionome and by $\mathrm{S}, \mathrm{Al}$, and $\mathrm{Fe}$ in the stem ionome. In the root ionome, the PC2 clearly distinguished between the neutral salt (CS and SS) treatments and the alkaline salt (AS) treatment, explaining 32.7\% of the total coefficient of variation. The elements $\mathrm{Ca}, \mathrm{Cu}, \mathrm{Zn}$, and $\mathrm{Co}$ were the dominant contributors to the PC2 in the root ionome.

In the hierarchical cluster analysis, the leaf, stem, and root ionomes of cotton were also separated on the basis of different types of salt-alkali stress (Figs. 7, 8, and 9, respectively), indicating high similarity among the ionomes in the samples from each treatment. In leaves (Fig. 7, Tables S1-S3), compared with the CK, the concentrations of $\mathrm{Na}, \mathrm{Zn}, \mathrm{Mn}, \mathrm{Fe}, \mathrm{B}, \mathrm{Mo}, \mathrm{Al}$, and Co increased significantly in the CS treatment; the concentrations of $\mathrm{Na}, \mathrm{S}, \mathrm{Zn}, \mathrm{Fe}, \mathrm{Mo}, \mathrm{Al}$, and Co increased significantly in the SS treatment; and the concentrations of $\mathrm{Na}, \mathrm{Fe}$, $\mathrm{Mn}, \mathrm{Zn}, \mathrm{Cu}, \mathrm{Mo}, \mathrm{Ni}, \mathrm{Co}, \mathrm{Al}$, and $\mathrm{Si}$ increased significantly in the AS treatment. By contrast, the concentrations of $\mathrm{P}, \mathrm{K}, \mathrm{Ca}, \mathrm{Mg}, \mathrm{S}$, and $\mathrm{Cu}$ decreased significantly in the $\mathrm{CS}$ treatment; the concentrations of $\mathrm{P}, \mathrm{Ca}, \mathrm{Mg}, \mathrm{B}, \mathrm{Cu}$, and Se decreased significantly in the SS treatment; and the concentrations of P, K, Ca, Mg, S, B, and Se decreased significantly in the AS treatment.

In the stems (Fig. 8, Tables S4-S6), compared with the CK, the concentrations of $\mathrm{Na}, \mathrm{Zn}, \mathrm{Mn}, \mathrm{Fe}, \mathrm{Mo}$, and $\mathrm{Al}$ increased significantly in the CS treatment; the concentrations of $\mathrm{Na}, \mathrm{S}, \mathrm{Zn}, \mathrm{Fe}, \mathrm{Mo}, \mathrm{Al}, \mathrm{Mn}$, and Co increased significantly in the SS treatment; and the concentrations of $\mathrm{Na}, \mathrm{Mn}, \mathrm{Zn}, \mathrm{Mo}, \mathrm{Ni}, \mathrm{Co}$, and B increased significantly in the AS treatment. By contrast, the concentrations of $\mathrm{B}, \mathrm{Ca}, \mathrm{Cu}, \mathrm{P}, \mathrm{K}, \mathrm{Mg}$, and $\mathrm{S}$ decreased significantly in the $\mathrm{CS}$ treatment; the concentrations of $\mathrm{P}, \mathrm{Ca}, \mathrm{Mg}$, and $\mathrm{Cu}$ decreased significantly in the SS treatment; and the concentrations of $\mathrm{Al}, \mathrm{Ca}, \mathrm{Cu}, \mathrm{Fe}, \mathrm{Mg}, \mathrm{P}$, and $\mathrm{S}$ decreased significantly in the AS treatment.

In the roots (Fig. 9, Tables S7-S9), compared with the CK, the concentrations of $\mathrm{Na}, \mathrm{P}, \mathrm{Mg}, \mathrm{Cu}, \mathrm{Zn}, \mathrm{Mn}, \mathrm{Co}$, $\mathrm{Mo}$, and $\mathrm{Al}$ increased significantly in the CS treatment; the concentrations of $\mathrm{Na}, \mathrm{Mg}, \mathrm{S}, \mathrm{Zn}, \mathrm{Fe}, \mathrm{Mo}, \mathrm{B}, \mathrm{Cu}, \mathrm{Al}$, $\mathrm{Mn}, \mathrm{Ni}$, and Co increased significantly in the SS treatment; and the concentrations of $\mathrm{Na}, \mathrm{Mg}, \mathrm{Mn}, \mathrm{Mo}, \mathrm{Ni}, \mathrm{Co}$, 


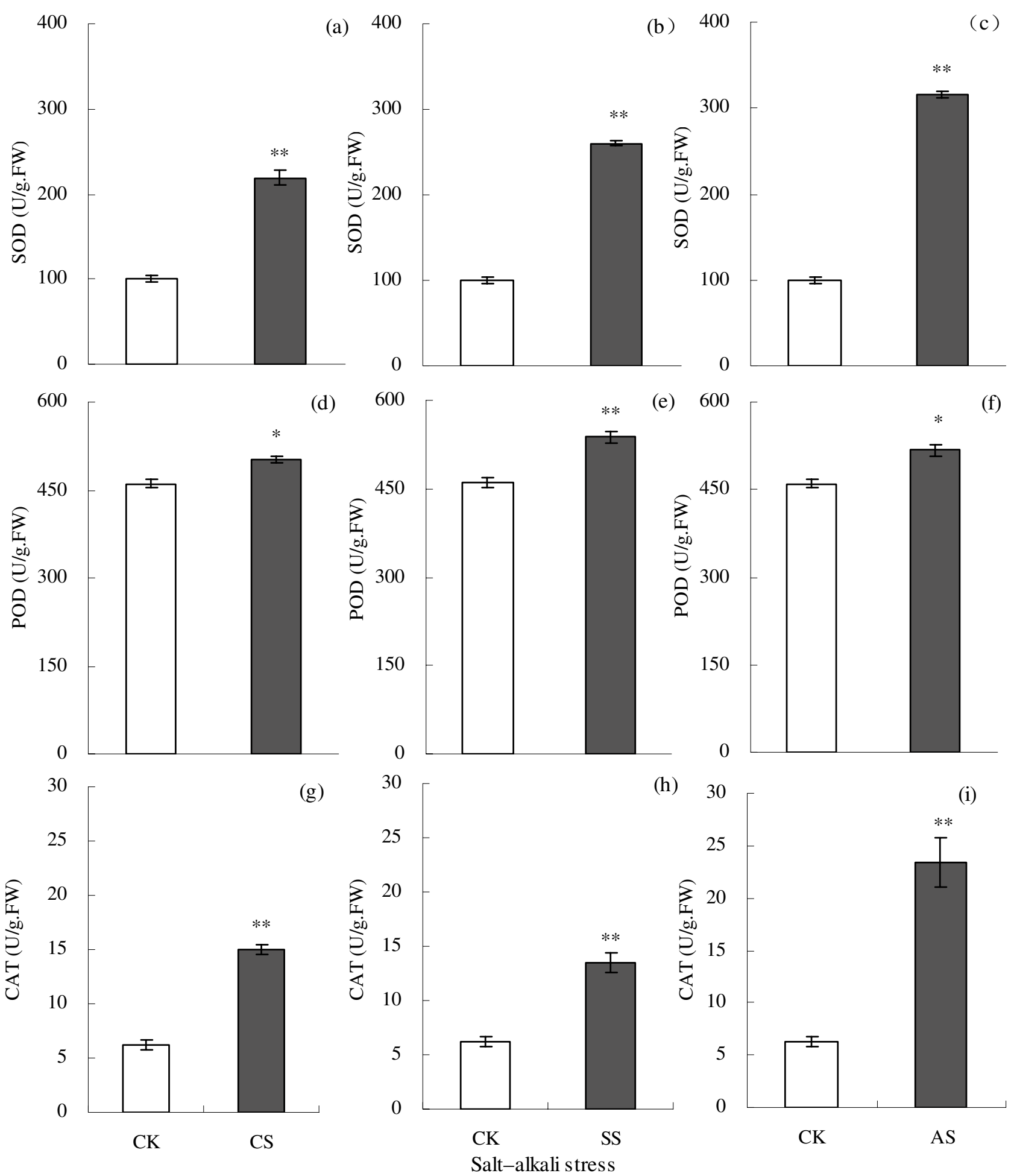

Figure 4. Activities (U/g fresh weight (FW)) of the antioxidant enzymes superoxide dismutase (SOD), peroxidase (POD), and catalase (CAT) in cotton leaves under different types of salt-alkali stress ( $\mathrm{NaCl}(\mathrm{CS})$, $\mathrm{Na}_{2} \mathrm{SO}_{4}(\mathrm{SS})$, and $\mathrm{Na}_{2} \mathrm{CO}_{3}+\mathrm{NaHCO}_{3}(\mathrm{AS})$ ). Columns with bars represent the mean \pm standard error $(n=3)$. Asterisks indicate a significant difference between the control (CK) and the salt-alkali stress $\left({ }^{*} p<0.05\right.$; $\left.{ }^{* *} p<0.01\right)$. (a-c) indicate the SOD in cotton leaves under $\mathrm{NaCl}, \mathrm{Na}_{2} \mathrm{SO}_{4}$, and $\mathrm{Na}_{2} \mathrm{CO}_{3}+\mathrm{NaHCO}_{3}$ stress, respectively. (d-f) indicate the POD in cotton leaves under $\mathrm{NaCl}, \mathrm{Na}_{2} \mathrm{SO}_{4}$, and $\mathrm{Na}_{2} \mathrm{CO}_{3}+\mathrm{NaHCO}_{3}$ stress, respectively. (g-i) indicate the CAT in cotton leaves under $\mathrm{NaCl}, \mathrm{Na}_{2} \mathrm{SO}_{4}$, and $\mathrm{Na}_{2} \mathrm{CO}_{3}+\mathrm{NaHCO}_{3}$ stress, respectively. 

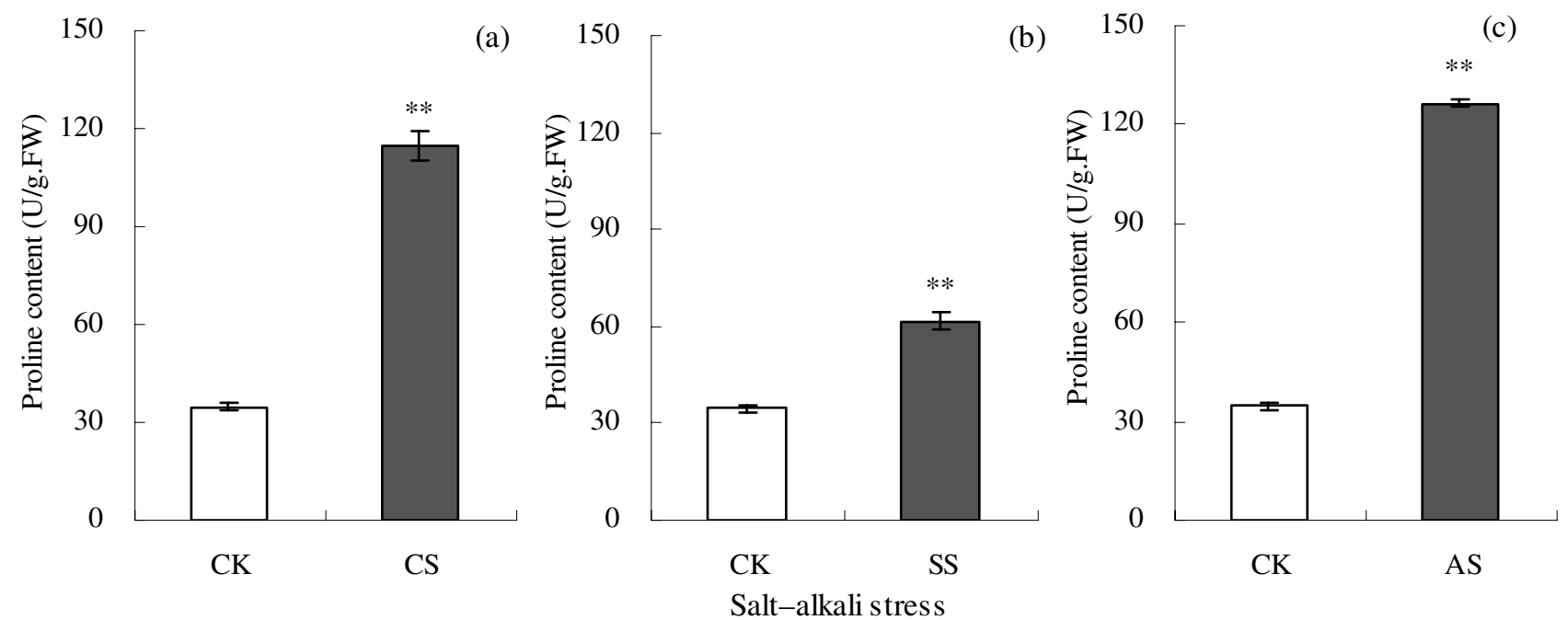

Figure 5. Proline content (U/g fresh weight (FW)) in cotton leaves under different types of salt-alkali stress $\left(\mathrm{NaCl}(\mathrm{CS}), \mathrm{Na}_{2} \mathrm{SO}_{4}(\mathrm{SS})\right.$, and $\mathrm{Na}_{2} \mathrm{CO}_{3}+\mathrm{NaHCO}_{3}(\mathrm{AS})$ ). Columns with bars represent the mean \pm standard error $(n=3)$. Asterisks indicate a significant difference between the control (CK) and the salt-alkali stress $\left({ }^{* *} p<0.01\right) .(\mathbf{a}-\mathbf{c})$ indicate the Proline content in cotton leaves under $\mathrm{NaCl}, \mathrm{Na}_{2} \mathrm{SO}_{4}$, and $\mathrm{Na}_{2} \mathrm{CO}_{3}+\mathrm{NaHCO}_{3}$ stress, respectively.

and B increased significantly in the AS treatment. By contrast, the concentration of Ca decreased significantly in the CS treatment; the concentrations of $\mathrm{P}$ and $\mathrm{Ca}$ decreased significantly in the SS treatment; and the concentrations of $\mathrm{Al}, \mathrm{Fe}, \mathrm{P}$, and $\mathrm{S}$ decreased significantly in the AS treatment.

Changes in $\mathrm{K} / \mathrm{Na}$ ratio after salt and alkali stresses. Salt-alkali stress significantly decreased the K/ $\mathrm{Na}$ ratio in cotton plants (Fig. 10). Compared with the CK, the K/Na ratio in cotton leaves was significantly lower by $87.46 \%$ in the CS treatment, by $92.58 \%$ in the SS treatment, and by $95.20 \%$ in the AS treatment; the K/Na ratio in cotton stems was significantly lower by $84.16 \%$ in the CS treatment, by $92.22 \%$ in the SS treatment, and by $94.44 \%$ in the AS treatment; and the $\mathrm{K} / \mathrm{Na}$ ratio in cotton roots was significantly lower by $76.92 \%$ in the CS treatment, by $84.43 \%$ in the SS treatment, and by $84.80 \%$ in the AS treatment.

Relationship between Na element and other elements. An excess of $\mathrm{Na}$ ions is the main cause of salt-alkali stress, and thus, it is essential to understand the correlations between $\mathrm{Na}$ and other elements. The correlations between $\mathrm{Na}$ and other elements in the leaf, stem, and root were analyzed under the different types of salt-alkali stress (Figs. 11, 12,13). In the CS treatment, the Na levels in the leaves were significantly negatively correlated with seven elements $(\mathrm{Cu}, \mathrm{Ca}, \mathrm{Mg}, \mathrm{K}, \mathrm{P}, \mathrm{S}$, and $\mathrm{Si})$ and significantly positively correlated with seven elements (Zn, Mo, Mn, Al, Fe, B, and Co), Ni and Se were negatively correlated with $\mathrm{Na}$, but the correlations were not significant (Fig. 11a). In the SS treatment, the Na levels in the leaves were significantly negatively correlated with six elements $(\mathrm{Ca}, \mathrm{B}, \mathrm{P}, \mathrm{Mg}$, Se, and $\mathrm{Cu}$ ) and significantly positively correlated with nine elements ( $\mathrm{Zn}$, Mo, $\mathrm{Al}, \mathrm{S}, \mathrm{Fe}, \mathrm{Co}, \mathrm{Si}, \mathrm{Mn}$, and K), but had a significantly negative correlation with $\mathrm{Ni}$ (Fig. 11b). In the AS treatment, the $\mathrm{Na}$ levels in the leaves were significantly negatively correlated with seven elements $(\mathrm{Ca}, \mathrm{Mg}, \mathrm{S}, \mathrm{K}, \mathrm{Se}, \mathrm{P}$, and B) and significantly positively correlated with nine elements ( $\mathrm{Zn}, \mathrm{Mo}, \mathrm{Mn}, \mathrm{Al}, \mathrm{Fe}, \mathrm{Co}, \mathrm{Cu}, \mathrm{Si}$, and Ni), but had a significantly negative correlation with $\mathrm{Ni}$ (Fig. 11c).

In the CS treatment, the $\mathrm{Na}$ levels in the stems were significantly negatively correlated with $\mathrm{Cu}, \mathrm{K}, \mathrm{Ca}, \mathrm{Mg}$, $\mathrm{P}, \mathrm{S}$, and B and significantly positively correlated with $\mathrm{Mo}, \mathrm{Zn}, \mathrm{Mn}, \mathrm{Al}, \mathrm{Fe}, \mathrm{Co}$, Se, and Si, but had a significantly negative correlation with $\mathrm{Ni}$ (Fig. 12a). In the SS treatment, the $\mathrm{Na}$ levels in the stems were significantly negatively correlated with $\mathrm{Cu}, \mathrm{Mg}, \mathrm{P}, \mathrm{Ca}$, and Se and significantly positively correlated with $\mathrm{Fe}, \mathrm{Al}, \mathrm{Mn}, \mathrm{Mo}, \mathrm{Zn}, \mathrm{S}, \mathrm{Co}, \mathrm{Si}$, and $\mathrm{B}$, but had significantly negative correlations with $\mathrm{K}$ and $\mathrm{Ni}$ (Fig. 12b). In the AS treatment, the Na levels in the stems were significantly negatively correlated with $\mathrm{Ca}, \mathrm{P}, \mathrm{Al}, \mathrm{Cu}, \mathrm{Mg}, \mathrm{S}, \mathrm{Fe}, \mathrm{Se}$, and $\mathrm{K}$ and significantly positively correlated with $\mathrm{Co}, \mathrm{Mn}, \mathrm{Mo}, \mathrm{Zn}, \mathrm{Ni}, \mathrm{B}$, and $\mathrm{Si}$ (Fig. 12c).

In the CS treatment, the Na levels in the roots were negatively correlated with $\mathrm{Ca}, \mathrm{K}, \mathrm{Fe}, \mathrm{Ni}$, B, and $\mathrm{Se}$ and significantly positively correlated with $\mathrm{Mg}, \mathrm{Zn}, \mathrm{Mo}, \mathrm{Co}, \mathrm{Mn}, \mathrm{Cu}, \mathrm{P}, \mathrm{Al}, \mathrm{S}$, and $\mathrm{Si}$ (Fig. 13a). In the SS treatment, the $\mathrm{Na}$ levels were significantly positively correlated with almost all elements, with $\mathrm{Ca}, \mathrm{P}$, and Se the exceptions (Fig. 13b). In the AS treatment, the Na levels in the roots were negatively correlated with $\mathrm{P}, \mathrm{Al}, \mathrm{Fe}, \mathrm{S}, \mathrm{Se}, \mathrm{Ca}$, and $\mathrm{Zn}$ and positively correlated with $\mathrm{Mg}, \mathrm{Mo}, \mathrm{Mn}, \mathrm{B}, \mathrm{Co}, \mathrm{Ni}, \mathrm{K}, \mathrm{Cu}$, and $\mathrm{Si}$ (Fig. 13c).

Changes in expression of GhSOS1 and GhNHX1 after salt and alkali stresses. To determine the changes in $\mathrm{Na}^{+}$transport-related genes of cotton under salt-alkali stress, the expression patterns of GhSOS1 and GhNHX1 were analyzed by RT-qPCR (Fig. 14). In the leaf, the expression of GhSOS1 increased significantly under salt stress but decreased significantly under alkali stress. However, in the roots, the expression levels of 

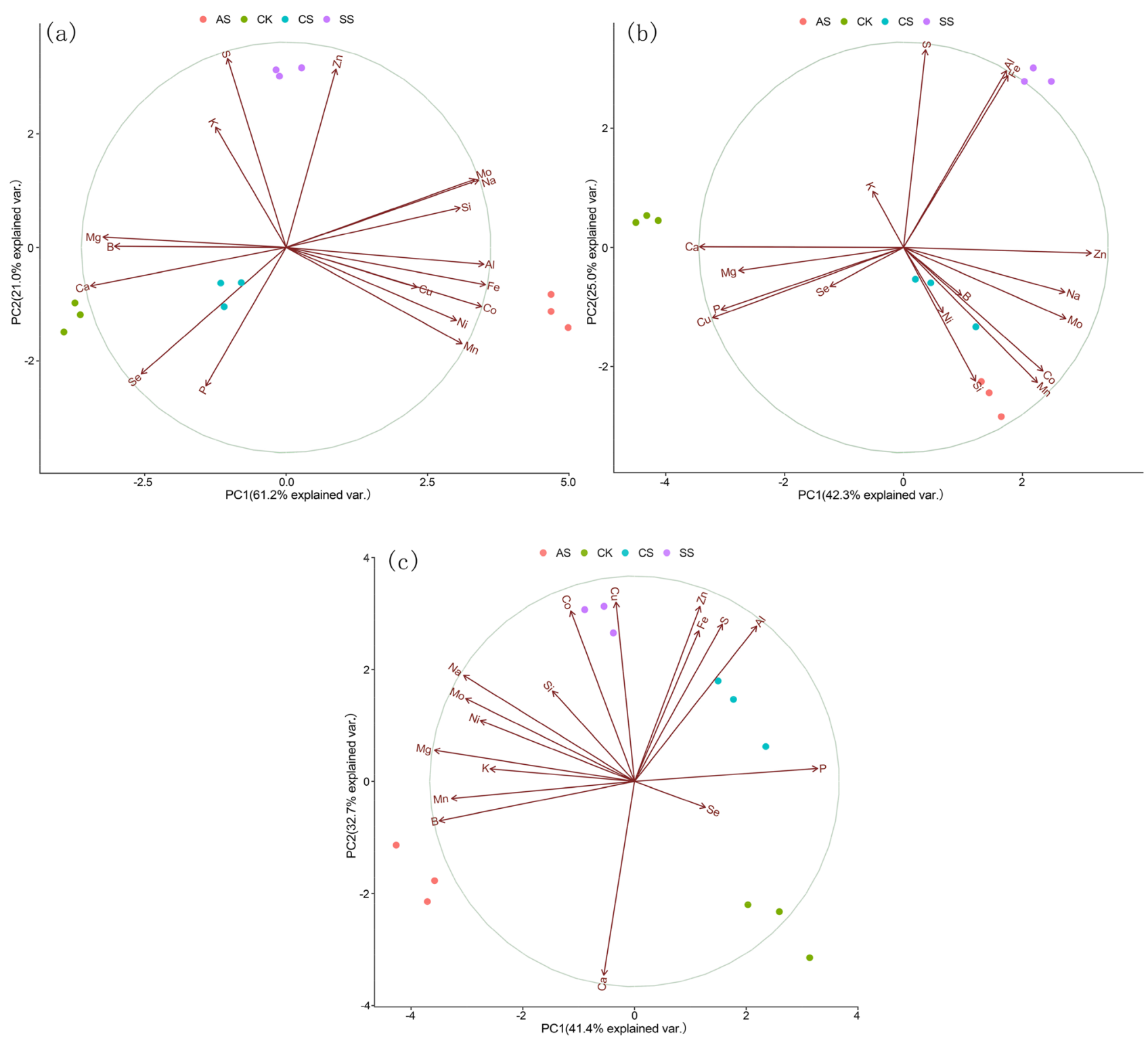

Figure 6. Principal component analysis (PCA) of tissue ionome variation in cotton under different types of salt-alkali stress (Control (CK), $\mathrm{NaCl}(\mathrm{CS}), \mathrm{Na}_{2} \mathrm{SO}_{4}$ (SS), and $\mathrm{Na}_{2} \mathrm{CO}_{3}+\mathrm{NaHCO}_{3}(\mathrm{AS})$ ), with the loadings of mineral elements to the PC1 and PC2. (a) Leaf ionome variation among samples and the loadings of elements to the PC1 and PC2; (b) Stem ionome variation among samples and the loadings of elements to the PC1 and PC2; (c) Root ionome variation among samples and the loadings of elements to the PC1 and PC2.

GhSOS1 decreased significantly in all salt-alkali treatments. The expression of GhNHX1 increased significantly in leaves and roots under salt stress treatments; however, the difference between the CK and AS treatments was not significant for either leaves or roots.

\section{Discussion}

Effects of salt and alkali stresses on cotton growth. Excessive soil salinity mainly causes damage to plants through osmotic stress and ion toxicity, and the inhibition of growth is the most common physiological response in a saline habitat ${ }^{25-27}$. In this study, salt-alkali stress significantly inhibited cotton growth. The inhibition might have been due to the toxicity of $\mathrm{Na}$ ions with salt stress ${ }^{28,29}$ and the increase in $\mathrm{pH}$ and disturbance of plant nutrition and metabolism with alkali stress ${ }^{30}$. In addition, salt-alkali stress reduced root length, surface area, and root volume in this study. Chachar et al. ${ }^{12}$ found similar results in cotton, with salt stress inhibiting the elongation of main roots and the occurrence of lateral roots.

Effects of salt and alkali stress on cotton physiological response. The structure and function of cell membranes are important in plant adaptability to adversity. Plants respond to salt stress by up-regulating protective enzymes, such as SOD, POD, and CAT, to increase the ability to scavenge reactive oxygen species $(\mathrm{ROS})^{31-34}$. Under normal physiological conditions in plants, the continuous production and consumption of 


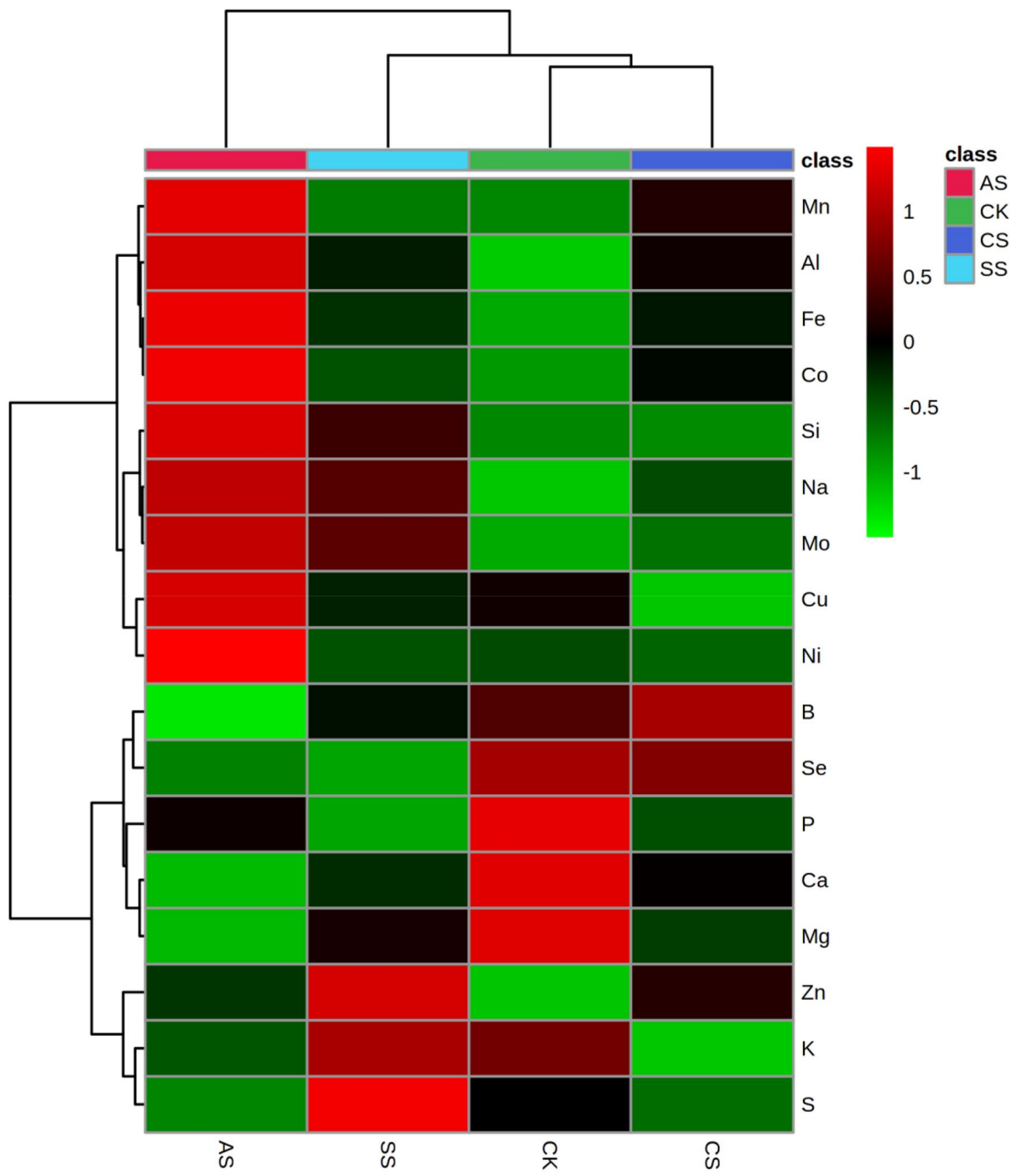

Figure 7. Hierarchical cluster analysis of the leaf ionomes in cotton plants under different types of salt-alkali stress (Control (CK), $\mathrm{NaCl}(\mathrm{CS}), \mathrm{Na}_{2} \mathrm{SO}_{4}(\mathrm{SS})$, and $\mathrm{Na}_{2} \mathrm{CO}_{3}+\mathrm{NaHCO}_{3}(\mathrm{AS})$ ). The relative values are indicated by color intensity in the legend in the upper right.

ROS are maintained in dynamic equilibrium, whereas salt stress destroys that dynamic equilibrium, resulting in the peroxidation and deacylation of membrane lipids. With such damage to the membrane system and metabolic processes, as well as to biological macromolecules such as proteins and nucleic acids, the result is cell death $^{35,36}$. In this study, salt-alkali stress significantly increased the REC of leaves. In addition, the REC under alkali stress was significantly lower than that under salt stress, indicating that salt stress was more harmful to the permeability of leaf cell membranes. By contrast, the MDA content was significantly higher under alkali stress than under salt stress, with the lowest MDA content under $\mathrm{Na}_{2} \mathrm{SO}_{4}$ stress, indicating greater damage by ROS under alkali stress. Chen et al. ${ }^{37}$ also found that with increases in soil salinity and $\mathrm{pH}$, both MDA content and REC increased significantly, especially at high soil salinity. Increasing the activity of antioxidant enzymes and the level of antioxidant metabolism is an important mechanism to improve the salt tolerance of plants. Moreover, SOD, POD, and CAT stabilize the ability to scavenge active oxygen-free radicals ${ }^{38}$. In this study, salt-alkali stress increased the activities of SOD, POD, and CAT in leaves. With a significant increase in SOD activity, the ability of leaves to scavenge oxygen-free radicals can increase, whereas with a significant increase in CAT activity, $\mathrm{H}_{2} \mathrm{O}_{2}$ 


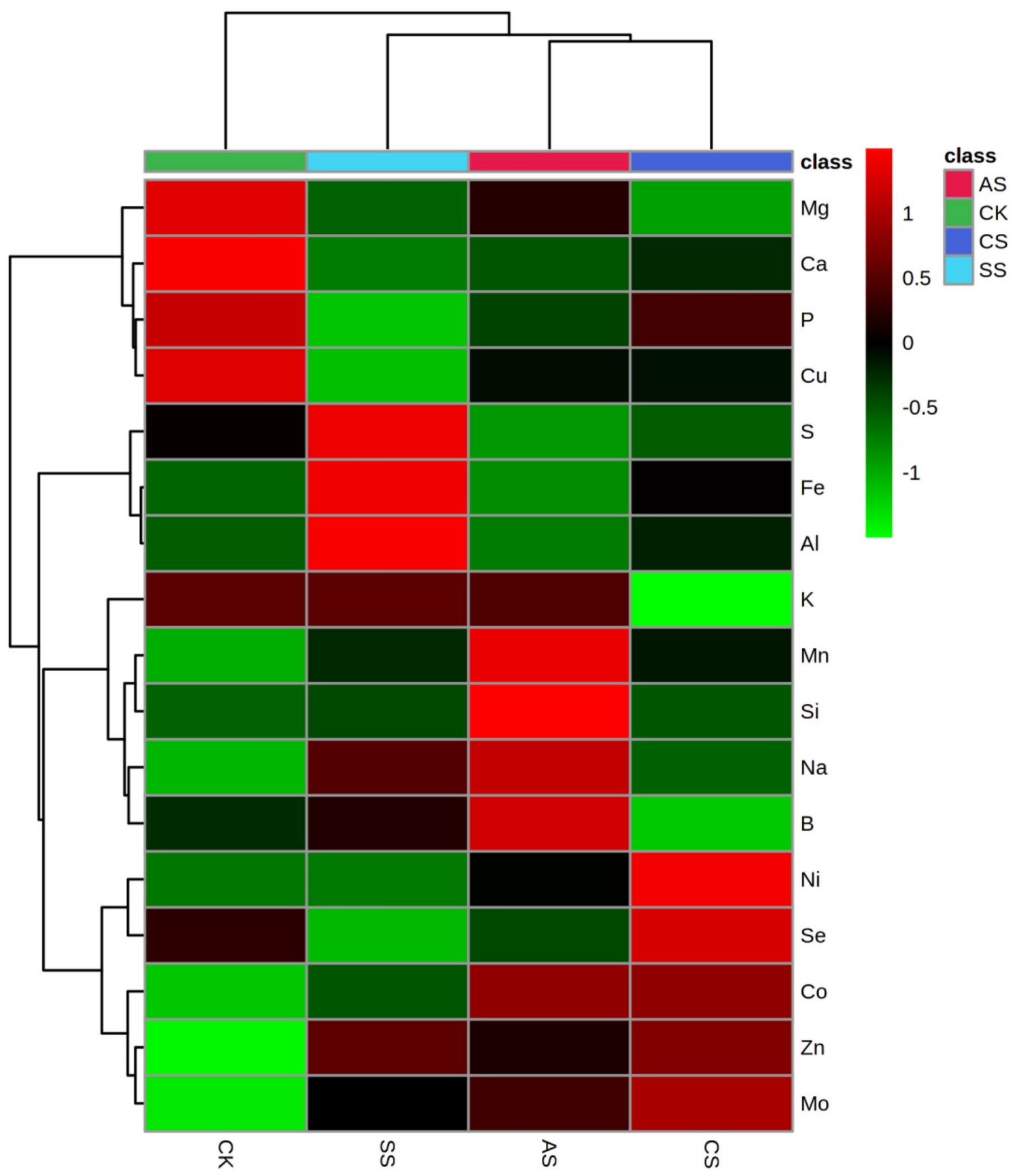

Figure 8. Hierarchical cluster analysis of the stem ionomes in cotton plants under different types of salt-alkali stress (Control (CK), $\mathrm{NaCl}(\mathrm{CS}), \mathrm{Na}_{2} \mathrm{SO}_{4}(\mathrm{SS})$, and $\mathrm{Na}_{2} \mathrm{CO}_{3}+\mathrm{NaHCO}_{3}(\mathrm{AS})$ ). The relative values are indicated by color intensity in the legend in the upper right.

can be eliminated by directly decomposing $\mathrm{H}_{2} \mathrm{O}_{2}$ into water and oxygen ${ }^{39}$. Zhang et al. ${ }^{40}$ and Ibrahim et al. ${ }^{41}$ also reported that salinity stress increases the activities of SOD, POD, and CAT in cotton leaves.

To protect themselves under salt stress, plants can also biosynthesize soluble compounds, such as carbohydrates, proline, and betaine, to adjust cellular osmotic conditions, maintain membrane integrity and function ${ }^{42,43}$, and stabilize enzyme activities. In addition, the increase in soil $\mathrm{pH}$ under alkali stress can inhibit the uptake of mineral elements by crops, and therefore, some crops secrete organic acids to activate mineral elements around the roots and resist the alkali stress. Proline is one of the organic acids, and its content might be higher under alkali stress. In this study, the Pro content was higher under alkali stress than under salt stress, which suggested that Pro played a more important role in resisting alkali stress. Several studies also show that Pro content increases with increasing soil salinity ${ }^{39,44,45}$.

Effects of salt and alkali stresses on cotton tissue ionomes. The absorption of nutrients by plants is inhibited by salt-alkali stress ${ }^{46,47}$, and the lack of a particular nutrient element changes the metabolism of plants 


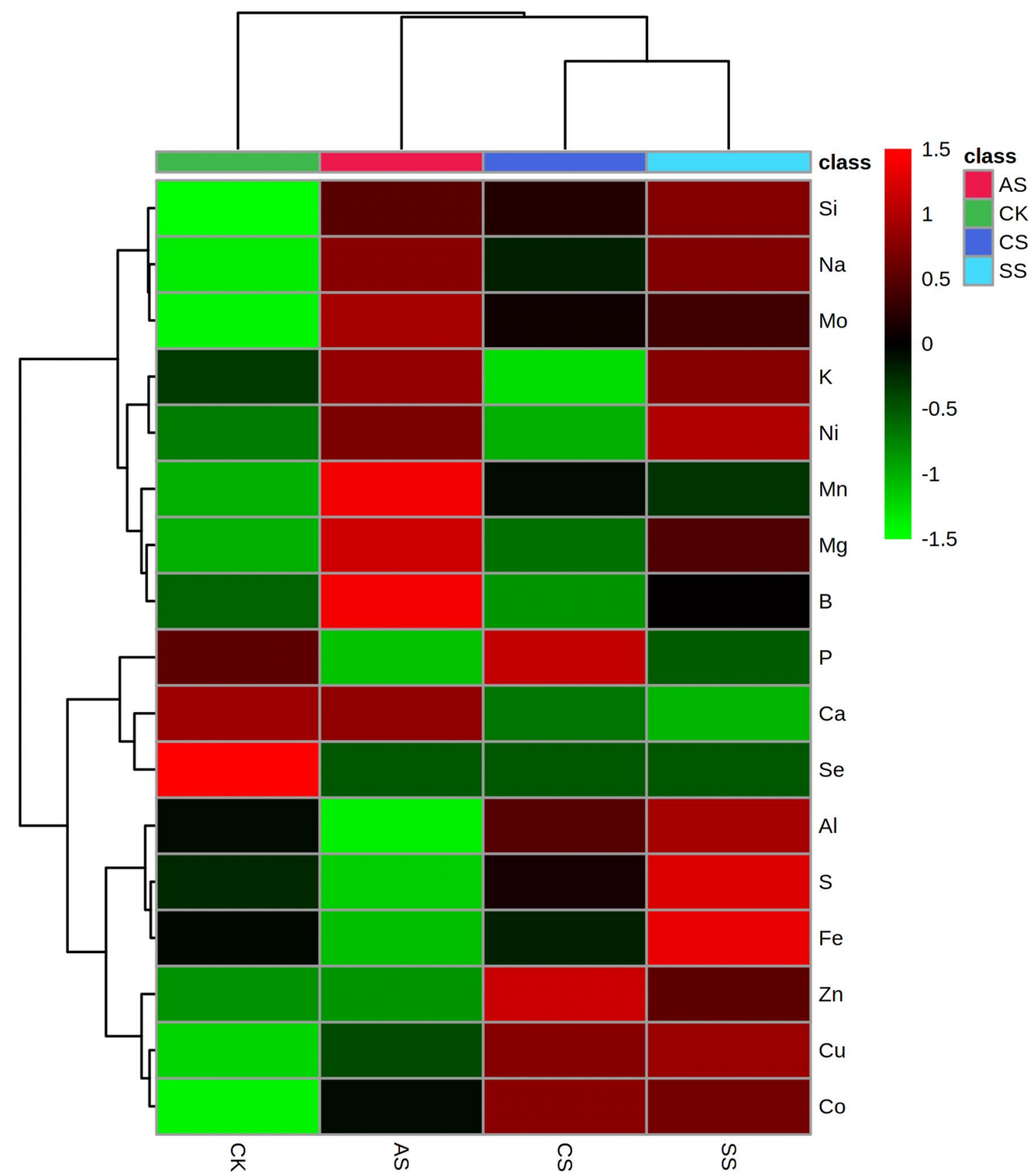

Figure 9. Hierarchical cluster analysis of the root ionomes in cotton plants under different types of salt-alkali stress (Control (CK), $\mathrm{NaCl}(\mathrm{CS}), \mathrm{Na}_{2} \mathrm{SO}_{4}(\mathrm{SS})$, and $\mathrm{Na}_{2} \mathrm{CO}_{3}+\mathrm{NaHCO}_{3}(\mathrm{AS})$ ). The relative values are indicated by color intensity in the legend in the upper right.

and affects the biosynthesis of metabolites. Salt stress is primarily caused by excess salt ions in soil, and rebuilding ion homeostasis under salt-alkali stress remains an important salt-tolerance strategy in plant cells ${ }^{13,48}$. Chen et al. ${ }^{37}$ suggest that osmotic adjustment by accumulating and absorbing inorganic ions such as $\mathrm{Na}^{+}, \mathrm{K}^{+}$, and $\mathrm{Ca}^{2+}$ in cells is an important salt-tolerance mechanism in plants; however, this adjustment can easily destroy the ion balance in cells and cause ion poisoning. Whether such ion poisoning will cause changes in other ions has become a focus of research. Wu et al. ${ }^{16}$ report that salt stress inhibits the uptake of macro and trace elements by crops, which leads to nutrient deficiency and cell metabolic disorder. In our experiment, the changes in ion groups in cotton under the three different types of salt-alkali stress were examined, and a total of 17 related ions were screened. According to PCAs, the elements that most strongly contributed to the first principal component were $\mathrm{Na}, \mathrm{Ca}, \mathrm{Mn}, \mathrm{Fe}, \mathrm{Mo}, \mathrm{Al}$, and $\mathrm{Co}$ in the leaf ionome; $\mathrm{Na}, \mathrm{P}, \mathrm{Ca}, \mathrm{Cu}, \mathrm{Zn}$, and $\mathrm{Mo}$ in the stem ionome; and $\mathrm{Na}$, $\mathrm{P}, \mathrm{Mg}, \mathrm{Mn}, \mathrm{Mo}$, and $\mathrm{B}$ in the root ionome.

In this study, salt-alkali stress increased the $\mathrm{Na}$ concentration in roots, stems, and leaves, with the concentration higher in leaves than in stems and roots, indicating that cotton could not prevent the transport of $\mathrm{Na}$ from the roots to the leaves. Consistent with the results of this study, Yang et al. ${ }^{30}$ also show that salt stress $(\mathrm{NaCl}$, 

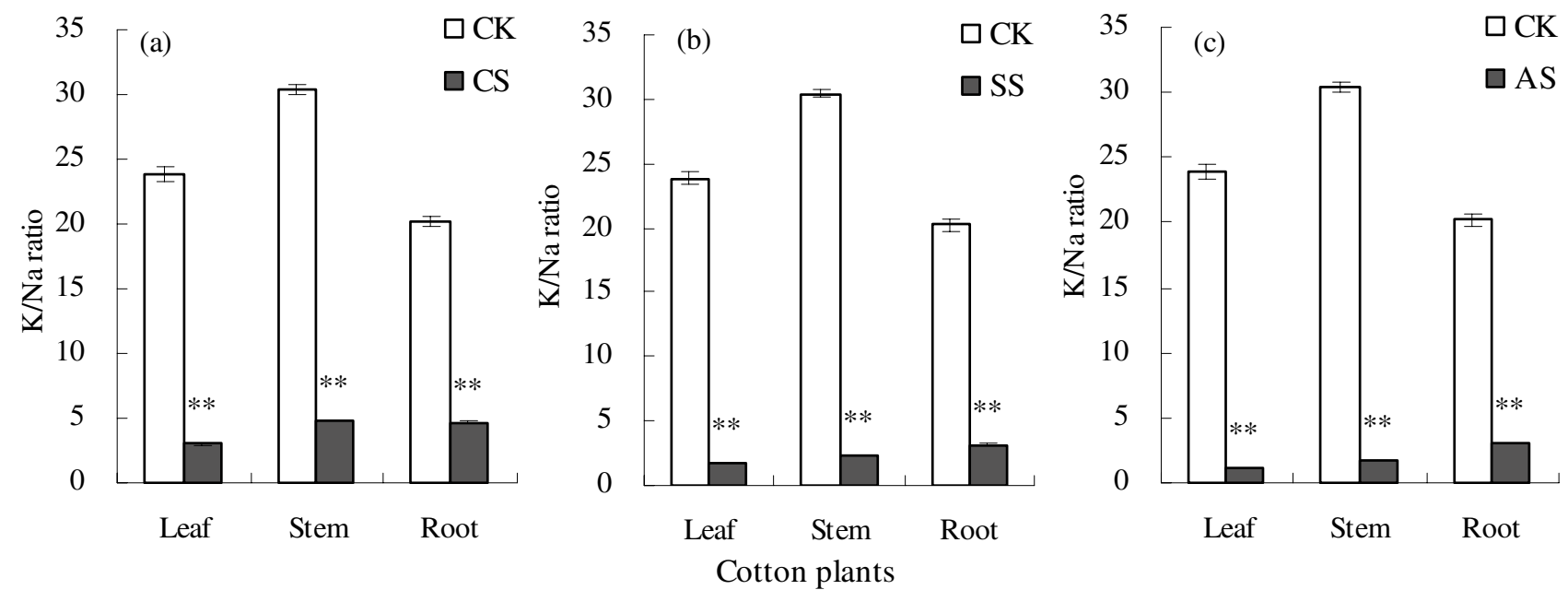

Figure 10. Leaf, stem, and root $\mathrm{K} / \mathrm{Na}$ ratios of cotton plants under different types of salt-alkali stress: (a) $\mathrm{NaCl}$ (CS), (b) $\mathrm{Na}_{2} \mathrm{SO}_{4}$ (SS), and (c) $\mathrm{Na}_{2} \mathrm{CO}_{3}+\mathrm{NaHCO}_{3}$ (AS). Columns with bars represent the mean \pm standard error $(n=3)$. Asterisks indicate a significant difference between the control $(\mathrm{CK})$ and the salt-alkali stress $\left({ }^{*} p<0.01\right)$.
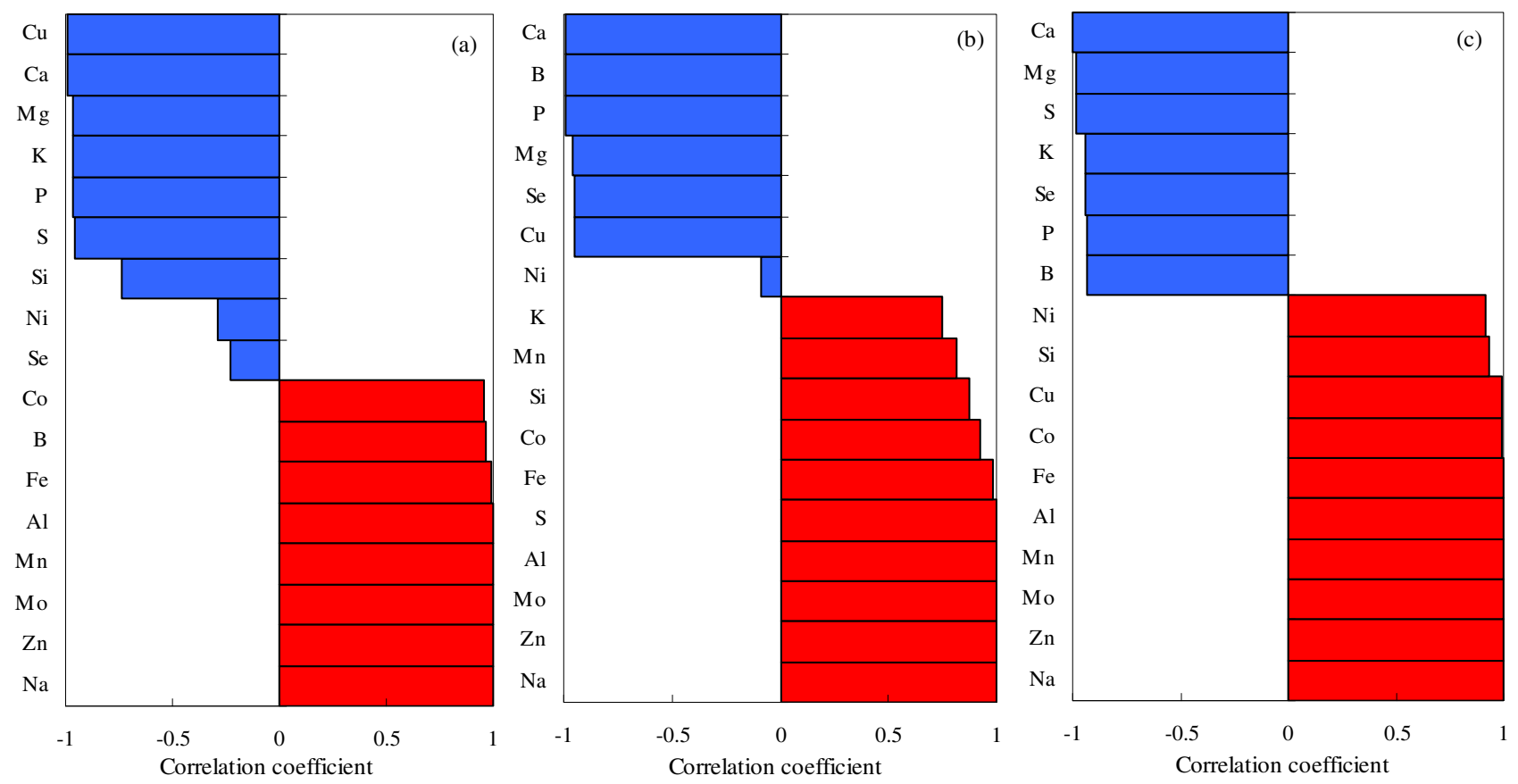

Figure 11. Pearson's coefficients of correlation between the element $\mathrm{Na}$ and other elements in cotton leaves under different types of salt-alkali stress. (a) $\mathrm{NaCl}$; (b) $\mathrm{Na}_{2} \mathrm{SO}_{4}$; and (c) $\mathrm{Na}_{2} \mathrm{CO}_{3}+\mathrm{NaHCO}_{3}$. Blue, negative correlation; red, positive correlation.

$\left.\mathrm{Na}_{2} \mathrm{SO}_{4}\right)$ and alkali stress $\left(\mathrm{NaHCO}_{3}, \mathrm{Na}_{2} \mathrm{CO}_{3}\right)$ increase the $\mathrm{Na}$ concentration in plants. In addition, we found that the increase in $\mathrm{Na}$ concentration was higher in leaves, stems, and roots under alkali stress than under salt stress. Wang et al. ${ }^{49}$ also observed that the $\mathrm{Na}^{+}$content is greater under alkali stress than under salt stress. Because more $\mathrm{Na}$ accumulates in the shoots than in the roots, the shoots are more sensitive to salt stress ${ }^{50,51}$. Cotton responds to salt stress by maintaining the balance of $\mathrm{K}$ and $\mathrm{Na}$ ions in tissues, and maintaining a relatively high $\mathrm{K} / \mathrm{Na}$ ratio in tissues is more important than simply maintaining a lower Na concentration ${ }^{52}$. In this study, salt-alkali stress significantly decreased the $\mathrm{K} / \mathrm{Na}$ ratio in cotton. The $\mathrm{K} / \mathrm{Na}$ ratio was higher under alkali stress than under salt stress. Potassium is an essential nutrient element for plants, and when the $\mathrm{Na}$ concentration is higher than the $\mathrm{K}$ concentration in the external environment, $\mathrm{Na}$ ions inhibit $\mathrm{K}$ uptake by plants through competitive action $^{53}$. Sodium can replace $\mathrm{K}$ at binding sites and thus inhibit the normal metabolism of plants. In this study, the leaf $\mathrm{K}$ concentration decreased under $\mathrm{NaCl}$ stress and alkali stress, but $\mathrm{Na}_{2} \mathrm{SO}_{4}$ and alkali stress had no significant effect on $\mathrm{K}$ absorption. This result might be attributed to an inhibitory effect of high $\mathrm{pH}$ on $\mathrm{K}$ transport, which 

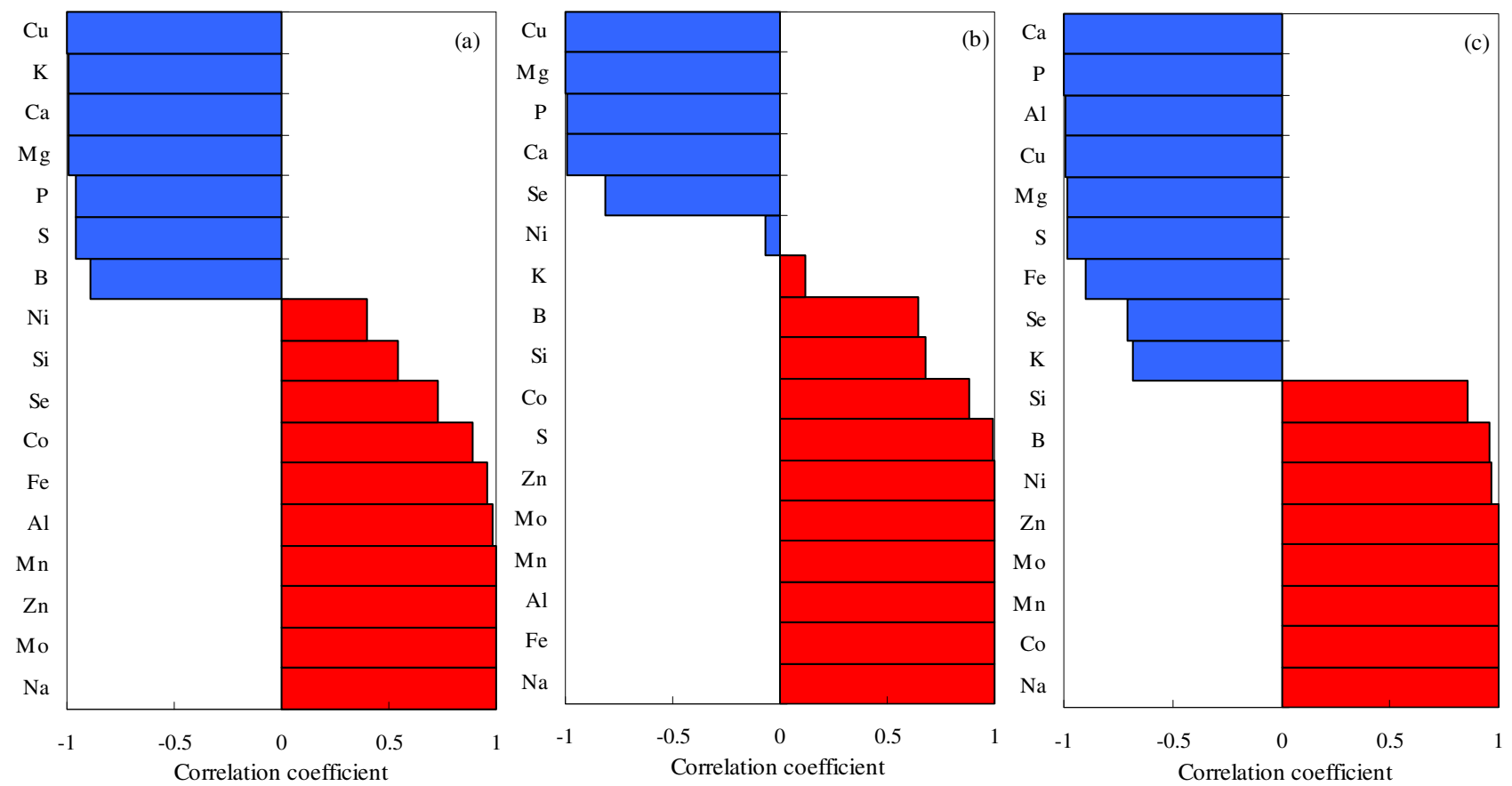

Figure 12. Pearson's coefficients of correlation between the element $\mathrm{Na}$ and other elements in cotton stems under different types of salt-alkali stress. (a) $\mathrm{NaCl}$; (b) $\mathrm{Na}_{2} \mathrm{SO}_{4}$; and (c) $\mathrm{Na}_{2} \mathrm{CO}_{3}+\mathrm{NaHCO}_{3}$. Blue, negative correlation; red, positive correlation.
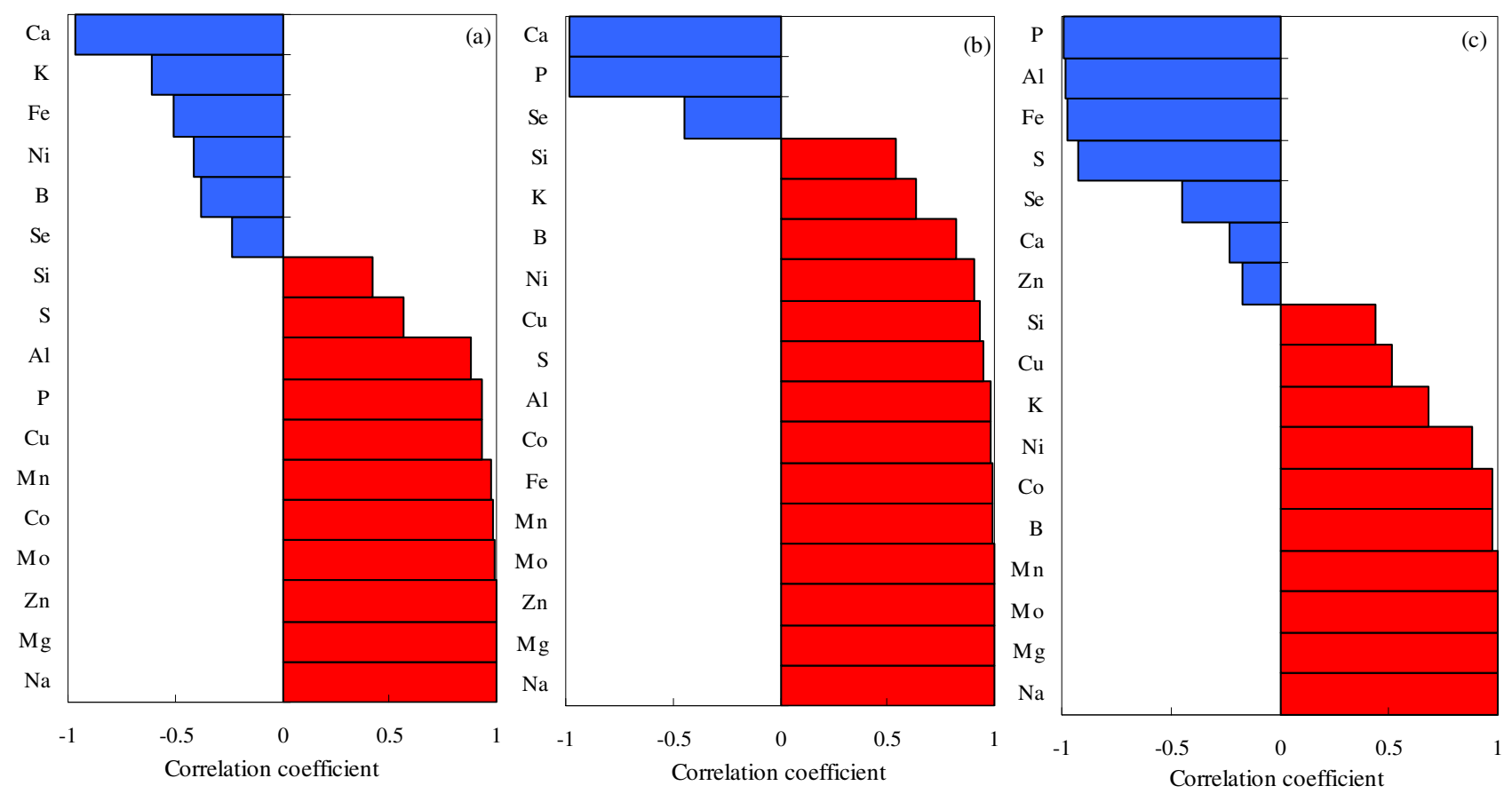

Figure 13. Pearson's coefficients of correlation between the element $\mathrm{Na}$ and other elements in cotton roots under different types of salt-alkali stress. (a) $\mathrm{NaCl}$; (b) $\mathrm{Na}_{2} \mathrm{SO}_{4}$; and (c) $\mathrm{Na}_{2} \mathrm{CO}_{3}+\mathrm{NaHCO}_{3}$. Blue, negative correlation; red, positive correlation.

relies on a transmembrane proton gradient ${ }^{49}$. Wang et al. ${ }^{11}$ also observed that salt stress significantly reduces the $\mathrm{K}$ concentration in cotton shoots and roots.

Salt-alkali stress inhibited $\mathrm{P}$ absorption in leaves, stems, and roots, which indicated that high-salt and high$\mathrm{pH}$ environments inhibit $\mathrm{P}$ absorption and transportation in cotton. The most likely explanations for these results are the following: (1) under salt stress, the high concentration of $\mathrm{Na}^{+}$and $\mathrm{Cl}^{-}$in plants results in a significant decrease in the concentrations of $\mathrm{K}^{+}, \mathrm{Ca}^{2+}$, and $\mathrm{P}$ in plant leaves and roots, which hinders normal cell 

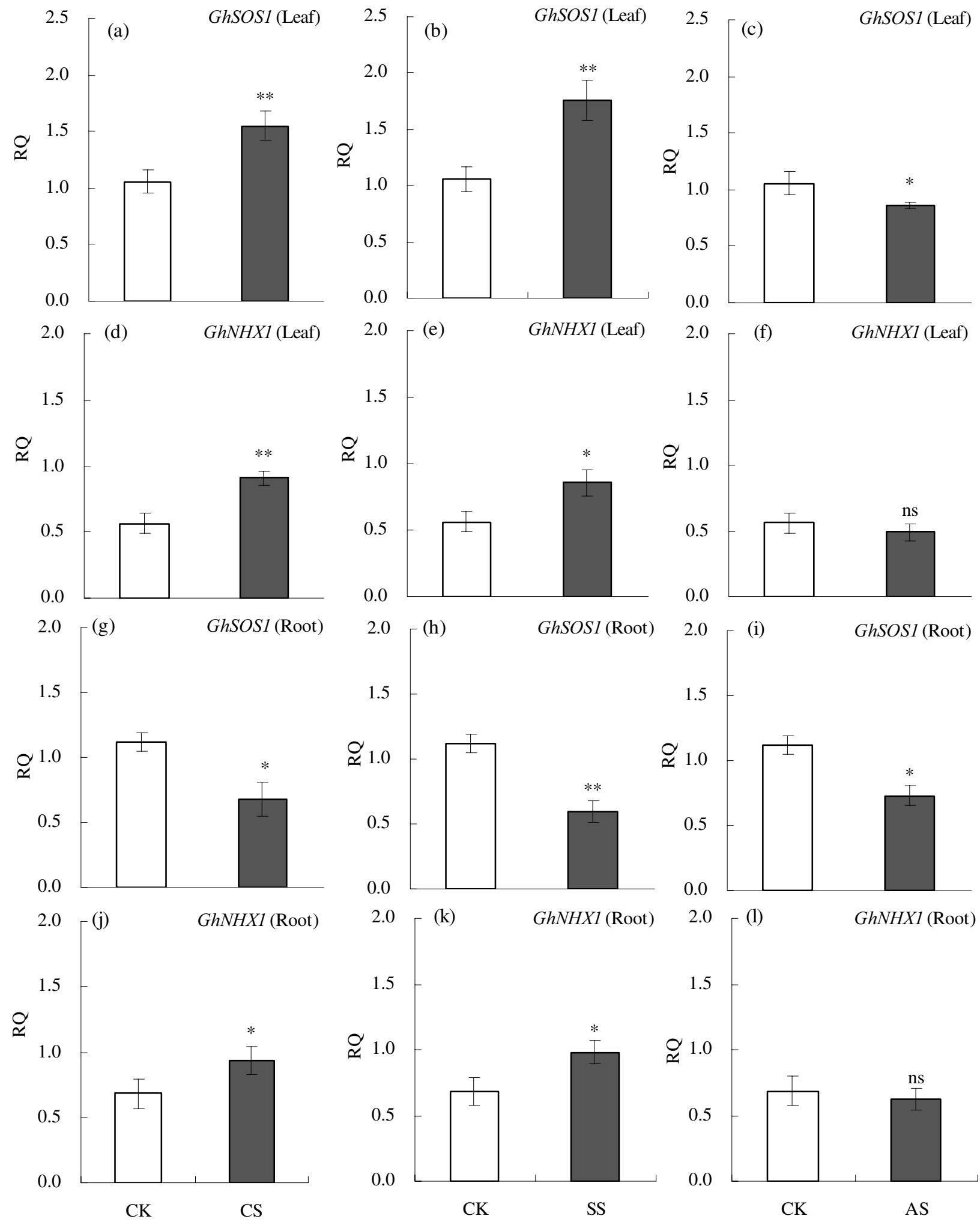

Figure 14. Relative expression (RQ) of the genes GhSOS1 and GhNHX1 in leaf and root of cotton under different types of saltalkali stress $\left(\mathrm{NaCl}(\mathrm{CS}), \mathrm{Na}_{2} \mathrm{SO}_{4}(\mathrm{SS})\right.$, and $\mathrm{Na}_{2} \mathrm{CO}_{3}+\mathrm{NaHCO}_{3}(\mathrm{AS})$ ). Columns with bars represent the mean \pm standard error $(n=3)$. Asterisks indicate a significant difference between the control (CK) and the salt-alkali stress $\left({ }^{*} p<0.05 ;{ }^{* *} p<0.01\right)$, and ns indicates no significant difference. (a-c) indicate the GhSOS1 gene relative expression in cotton leaf under $\mathrm{NaCl}_{2} \mathrm{Na}_{2} \mathrm{SO}_{4}$, and $\mathrm{Na}_{2} \mathrm{CO}_{3}+\mathrm{NaHCO}_{3}$ stress, respectively. (d-f) indicate the GhNHX1 gene relative expression in cotton leaf under $\mathrm{NaCl}_{2} \mathrm{Na}_{2} \mathrm{SO}_{4}$, and $\mathrm{Na}_{2} \mathrm{CO}_{3}+\mathrm{NaHCO}_{3}$ stress, respectively. ( $($ - $-\mathbf{i})$ indicate the GhSOS1 gene relative expression in cotton root under $\mathrm{NaCl}, \mathrm{Na}_{2} \mathrm{SO}_{4}$, and $\mathrm{Na}_{2} \mathrm{CO}_{3}+\mathrm{NaHCO}_{3}$ stress, respectively. (j-l) indicate the GhNHX1 gene relative expression in cotton root under $\mathrm{NaCl}, \mathrm{Na}_{2} \mathrm{SO}_{4}$, and $\mathrm{Na}_{2} \mathrm{CO}_{3}+\mathrm{NaHCO}_{3}$ stress, respectively. 
metabolism and material transportation ${ }^{54}$; and (2) under alkali stress, with high soil $\mathrm{pH}, \mathrm{Na}^{+}, \mathrm{Cl}^{-}$, and $\mathrm{CO}_{3}{ }^{2+}$ ions compete with available $\mathrm{P}$ and exchangeable calcium combines with $\mathrm{P}$ to form insoluble calcium phosphate salts, which result in a sharp decrease in the concentration of available $\mathrm{P}$ in the rhizosphere of crops $^{55,56}$. Sulfur is a component of amino acids in enzymes and other proteins and is involved in the formation of chlorophyll and the metabolism of carbohydrates. In this study, under $\mathrm{NaCl}$ and alkali stresses, the concentration of $\mathrm{S}$ in leaves decreased, but under $\mathrm{Na}_{2} \mathrm{SO}_{4}$ stress, the concentration of $\mathrm{S}$ increased significantly in roots, stems, and leaves, most likely because of the addition of $\mathrm{SO}_{4}{ }^{2-}$. In addition to $\mathrm{K}, \mathrm{Ca}$ and $\mathrm{Mg}$ are also important in improving the salt tolerance of cotton ${ }^{57,58}$. Calcium and $\mathrm{Na}$ interact antagonistically, and excessive Na intake leads to a relative deficiency of $\mathrm{Ca}$ in cotton. The findings in this study are similar to those of Zhang et al ${ }^{59}$ who reported that salt stress significantly decreases the Ca concentration in plants. However, Severino et al. ${ }^{60}$ showed that $\mathrm{Ca}$ and $\mathrm{Mg}$ do not reduce Na toxicity at the seedling stage of cotton. In this study, salt-alkali stress significantly increased the $\mathrm{Mg}$ concentration in roots but significantly decreased the concentration in leaves, indicating that salt-alkali stress inhibited the transport of $\mathrm{Mg}$. The significant decrease in the $\mathrm{Mg}$ concentration in leaves might be due to lower chlorophyll concentration in the leaves after salt stress ${ }^{59}$.

The essential micronutrient elements in plants are $\mathrm{Fe}, \mathrm{Mn}, \mathrm{Cu}, \mathrm{Zn}, \mathrm{B}$, and Mo, which are components of enzymes or coenzymes in plants, with strong specificity. Competition and interaction between soluble salts and mineral nutrients can lead to nutritional disequilibrium and deficiency ${ }^{61}$. Iron is an essential component in chlorophyll biosynthesis and respiration and is associated with enzymes. In this study, salt-alkali stress significantly increased the Fe concentration in leaves. The increase might be because cotton responded to salt-alkali stress by biosynthesizing chlorophyll in order to increase photosynthesis and maintain growth. Manganese has a catalytic role in chlorophyll biosynthesis, which is closely related to photosynthesis and respiration in plants. In our study, salt-alkali stress increased the Mn concentration in cotton plants. However, Karimi et al ${ }^{62}$ reported that excessive accumulation of $\mathrm{Na}$ reduces the absorption of $\mathrm{Mn}$. Copper is a component of some proteins in plants and participates in photosynthesis, in addition to increasing the stability of chloroplasts. In this study, both salt and alkali stress increased the $\mathrm{Cu}$ concentration in roots. However, salt stress decreased the $\mathrm{Cu}$ concentration in leaves, whereas alkali stress increased the $\mathrm{Cu}$ concentration in the leaves. Zinc is involved in the biosynthesis of auxins, and with a lack of $\mathrm{Zn}$, crop growth and development are inhibited. To maintain their growth in a stressed environment, plants can promote the absorption of Zn. In this study, neutral salt stress significantly increased the $\mathrm{Zn}$ concentration in root, stem, and leaf, whereas alkali stress significantly increased the $\mathrm{Zn}$ concentration in stem and leaf. These results showed that salt stress promoted the absorption and transport of $\mathrm{Zn}$, whereas alkali stress only promoted the transport of $\mathrm{Zn}$ to the shoots. Boron promotes carbohydrate transport and metabolism. In this study, $\mathrm{Na}_{2} \mathrm{SO}_{4}$ stress and alkali stress increased the $\mathrm{B}$ concentration in roots but decreased the concentration in leaves. However, $\mathrm{NaCl}$ stress showed the opposite effect. Molybdenum is the main component of nitrate reductase, which directly affects nitrogen metabolism. In this study, the Mo concentration in leaves, stems, and roots of cotton increased significantly under the different types of salt-alkali stress and was also significantly positively correlated with the Na concentration. Tang et al. ${ }^{63}$ found that the application of Mo can increase the salt tolerance of cotton, with the effectiveness of Mo increasing as the soil $\mathrm{pH}$ increased. Therefore, Mo can affect the salt and alkali resistance of cotton. We also found that alkali stress significantly increased the concentration of $\mathrm{Ni}$ in cotton roots, stems, and leaves, indicating that alkali stress promoted the absorption and transport of $\mathrm{Ni}$, suggesting it may play an important role in cotton resistance to alkali stress. Silicon, Co, Se, and $\mathrm{Al}$ are beneficial elements, and changes in their concentrations are caused by changes in other ions, which are companion ions and are not associated with salt and alkali resistance in plants.

On the basis of the comparative analysis of the three ionomes in cotton under salt-alkali stress, the inhibition of ion absorption was greater under alkali stress than under salt stress, because the concentrations of more elements were reduced in roots, stems, and leaves under alkali stress than under neutral salt stress. Therefore, under neutral salt stress, the absorption of only individual ions decreased, and as a result, neutral salt stress mainly disrupted the ion balance. However, alkali stress also inhibited the absorption of mineral elements, in addition to disrupting the ion balance.

Effects of salt and alkali stresses on expression of GhSOS1 and GhNHX1. The key ion that affects the ion homeostasis of cotton under saline-alkali stress is $\mathrm{Na}^{+}$. Therefore, it is critical to study the molecular mechanisms involving $\mathrm{Na}^{+}$to better understand the changes in ion homeostasis. GhSOS1 and GhNHX1 are two key salt-tolerance genes of cotton. GhSOS1 mainly regulates the plasma membrane $\mathrm{Na}^{+} / \mathrm{H}^{+}$antiporter, which can exclude excess $\mathrm{Na}^{+}$from the cytoplasm ${ }^{19,64}$. In our study, the relative expression of GhSOS1 increased significantly in cotton leaves and roots under neutral salt $\left(\mathrm{NaCl}\right.$ and $\left.\mathrm{Na}_{2} \mathrm{SO}_{4}\right)$ stress, but under alkali stress, the relative expression decreased significantly, indicating that high $\mathrm{pH}$ could inhibit GhSOS1 expression in leaf cells. This result might explain the different ion changes in cotton and was also consistent with the results for $\mathrm{Na}$ in the cotton ionome under alkali stress. GhNHX1 is a vacuolar membrane-bound $\mathrm{Na}^{+} / \mathrm{H}^{+}$antiporter, which can transport $\mathrm{Na}^{+}$from the cytoplasm into vacuoles and reduce the toxicity of excess $\mathrm{Na}^{+}$in the cytoplasm, thereby regulating ion homeostasis in cotton ${ }^{20,65}$. In our study, salt stress significantly increased the relative expression of GhNHX1 in roots and leaves. The up-regulation of GhNHX1 under salt stress could help cotton to isolate excess $\mathrm{Na}^{+}$and regulate ion homeostasis. In addition, alkali stress reduced the relative expression of GhNHX1 somewhat in this study, but the effect was not significant. It may be that when the degree of alkali stress reaches a critical level in cotton growth, the salt tolerance mechanisms are destroyed, including a decline in GhNHX1 expression. In previous studies, the overexpression of $S O S 1^{66}$ or $N H X 1^{67}$ in transgenic plants increases salt tolerance. 


\begin{tabular}{|c|c|c|c|}
\hline Treatment & Salinity and alkalinity & $\mathrm{EC}_{1: 5}\left(\mathrm{dS} \mathrm{m}^{-1}\right)$ & pH (1:2.5) \\
\hline Control (CK) & No salinization or alkalization & 0.35 & 8.16 \\
\hline $\mathrm{NaCl}(\mathrm{CS})$ & Moderate salinization & 1.39 & 8.43 \\
\hline $\mathrm{Na}_{2} \mathrm{SO}_{4}(\mathrm{SS})$ & Moderate salinization & 2.01 & 8.19 \\
\hline $\mathrm{Na}_{2} \mathrm{CO}_{3}+\mathrm{NaHCO}_{3}(\mathrm{AS})$ & Moderate alkalization & 0.63 & 9.92 \\
\hline
\end{tabular}

Table 1. Type and degree of saline and alkaline stress in the soils of different treatments.

\section{Conclusions}

Salt-alkali stress inhibited cotton growth and reduced root length, surface area, and volume, and the K/Na ratio of cotton, but increased REC, MDA, PRO content and antioxidant enzyme activities. Alkali stress inhibited ion absorption more than salt stress. Although neutral salt stress mainly disrupted the ion balance, alkali stress also inhibited the absorption of mineral elements, in addition to disrupting the ion balance. Cotton can adapt to salt-alkali stress through the formation of new ionic homeostasis. However, strategies differ in cotton under salt-alkali stress. Under $\mathrm{NaCl}$ stress, the absorption of $\mathrm{Ca}$ in cotton is inhibited, the transport capacity of $\mathrm{P}, \mathrm{Mg}$, and $\mathrm{Cu}$ is reduced, and the ion balance is maintained by promoting the absorption and transport of $\mathrm{Zn}, \mathrm{Mn}, \mathrm{Al}$, and Mo; Under $\mathrm{Na}_{2} \mathrm{SO}_{4}$ stress, the absorption of $\mathrm{P}$ and $\mathrm{Ca}$ in cotton is inhibited, the transport capacity of $\mathrm{Mg}$, $\mathrm{B}$, and $\mathrm{Cu}$ is reduced, and the ion balance is maintained by promoting the uptake and transport of $\mathrm{S}, \mathrm{Zn}, \mathrm{Fe}$, $\mathrm{Mo}, \mathrm{Al}$, and $\mathrm{Co}$; Under $\mathrm{Na}_{2} \mathrm{CO}_{3}+\mathrm{NaHCO}_{3}$ stress, the absorption of $\mathrm{P}$ and $\mathrm{S}$ in cotton is inhibited, the transport capacity of $\mathrm{Mg}$ and $\mathrm{B}$ is reduced, and the ion balance is maintained by promoting the absorption and transport of $\mathrm{Mn}, \mathrm{Mo}, \mathrm{Ni}$, and $\mathrm{Co}$. In addition, the relative expression of GhSOS1 and GhNHX1 in leaves decreased under $\mathrm{Na}_{2} \mathrm{CO}_{3}+\mathrm{NaHCO}_{3}$ stress but increased significantly under $\mathrm{NaCl}$ and $\mathrm{Na}_{2} \mathrm{SO}_{4}$ stress. The changes in the expression of GhSOS1 and GhNHX1 might partially explain the accumulation of Na ions under different types of salt-alkali stress in cotton.

\section{Materials and methods}

Materials. The experiment was conducted in a greenhouse at the experimental station $\left(\mathrm{N} 44^{\circ} 18^{\prime}, \mathrm{E} 86^{\circ} 02^{\prime}\right)$ of the College of Agriculture, Shihezi University, China, in 2019. The soil used in the experiment was collected from the 0 to $30-\mathrm{cm}$ depth at the experimental station. The soil type was grey desert soil with a loam texture, and the basic soil properties were as follow: soil salinity, $0.35 \mathrm{dS} \mathrm{m}{ }^{-1}$; $\mathrm{pH}, 7.86$; total nitrogen, $0.58 \mathrm{~g} \mathrm{~kg}^{-1}$; organic matter, $9.45 \mathrm{~g} \mathrm{~kg}^{-1}$; available phosphorus, $6.71 \mathrm{mg} \mathrm{kg}^{-1}$; available potassium, $142 \mathrm{mg} \mathrm{kg}^{-1}$. The cotton cultivar was Lu-mian-yan No. 24.

Experimental design. Three common types of soil salinization were tested in the experiment, including chloride $(\mathrm{NaCl}, \mathrm{CS})$, sulfate $\left(\mathrm{Na}_{2} \mathrm{SO}_{4}, \mathrm{SS}\right)$, and carbonate $\left(\mathrm{Na}_{2} \mathrm{CO}_{3}+\mathrm{NaHCO}_{3}, \mathrm{AS}\right)$. Non-salt-alkali stress was set as the control. There were three replicates of each treatment. The specific experimental treatments, i.e., soil salinization types, and their salinization degree are shown in Table 1.

Before initiating the experiment, the field-collected soil was naturally dried, crushed, and passed through a 2-mm sieve. Then, the solutions of $\mathrm{NaCl}, \mathrm{Na}_{2} \mathrm{SO}_{4}$, or $\mathrm{Na}_{2} \mathrm{CO}_{3}+\mathrm{NaHCO}_{3}$ (weight ratio 1:1) at different concentrations were added to the soil to produce a supersaturated state (the same volume of deionized water was added to the control soil) for 1 month to achieve the equilibrium of the soil. Thus, three different types of salt soils were formed. Then, the three types of saline soil were naturally dried, crushed, and passed through a 2-mm sieve. Soil columns that were $20 \mathrm{~cm}$ in diameter and $60 \mathrm{~cm}$ in height were prepared. The soil was layered to the $50-\mathrm{cm}$ depth at the soil bulk density of $1.25 \mathrm{~g} \mathrm{~cm}^{-3}$, with $10 \mathrm{~cm}$ per layer and $20 \mathrm{~kg}$ per soil column. The columns were drip-irrigated, and the emitters (columns) were $0.4 \mathrm{~m}$ apart with a discharge rate (pressure compensated) of $2.1 \mathrm{~L} \mathrm{~h}^{-1}$. The drip irrigation pipe was laid flat on the surface of the soil columns, with each soil column supplied by one emitter fixed at the center of the top of the column.

Cotton was sowed on 28 April 2019, and 10 seeds were sown per soil column. To ensure cotton emergence, each soil column was irrigated with $3 \mathrm{~L}$ of water after sowing. When the cotton seedlings reached the " 2 leaves and 1 heart" stage, two cotton seedlings with uniform growth were retained in each soil column. To ensure an adequate water supply, water was replenished by drip irrigation at regular intervals during the experiment to maintain the soil moisture content at $60 \%$ to $80 \%$ of field capacity. The experiment ended 60 days after sowing.

Sample collection and treatment. Growth. To determine the dry matter of cotton, three representative cotton plants were selected in each treatment. The roots, stems, and leaves were separated in the laboratory, and the fresh material was heat-treated at $105^{\circ} \mathrm{C}$ for $30 \mathrm{~min}$. Then, the materials were oven-dried at $70{ }^{\circ} \mathrm{C}$ for $48 \mathrm{~h}$, weighed, ground to pass through a 1-mm sieve, and stored at room temperature.

Root morphology. To collect the roots, a soil column (soil + root system) was put in a nylon net, and the soil was washed away in running water. The intact root system was removed and stored in a ziplock bag in an ultra-low temperature refrigerator. Roots were scanned with a flatbed image scanner (Epson Expression 1600 scanner). To determine root length, surface area, and volume, the images were analyzed using WinRhizo software (V5.0, Regent Instruments, Quebec, Canada). 


\begin{tabular}{|l|l|l|}
\hline Gene name & Annotation & Sequence $\mathbf{5}^{\prime}-\mathbf{3}^{\prime}$ \\
\hline \multirow{2}{*}{ UBQ7 } & & F: GAAGGCATTCCACCTGACCAAC \\
\cline { 3 - 3 } & & R: CTTGACCTTCTTCTTCTTGTGCTTG \\
\hline \multirow{2}{*}{ GhSOS1 } & \multirow{2}{*}{ Plasma membrane $\mathrm{Na}^{+} / \mathrm{H}^{+}$antiporter } & F: AGTGTCAGCCAATAAACAACC \\
\cline { 3 - 3 } & & R: TCTTTCGTGTCCATCTTCTTC \\
\hline \multirow{2}{*}{ GhNHX1 } & \multirow{2}{*}{ Tonoplast $\mathrm{Na}^{+} / \mathrm{H}^{+}$antiporter } & F: TTCTCTTTCTTTATGTCGGGATG \\
\cline { 3 - 3 } & & R: AACAAGACCCATCAGCACAGC \\
\hline
\end{tabular}

Table 2. Primers used to determine gene expression in reverse-transcription quantitative PCR.

Relative electrical conductivity, malondialdehyde, and antioxidant enzyme activity. Sixty days after cotton seedling emergence, all functional leaves on the main stem (the third leaves on the main stem were completely unfolded) were collected in each treatment and then transported to the laboratory in an icebox. The dust and dirt on leaf surfaces were removed; the moisture on the surface was wiped with an absorbent paper; and the main vein was removed. The relative electrical conductivity (REC) of leaves was measured by the conductance method. The malondialdehyde (MDA) content in leaves was measured according to $\mathrm{Wu}$ et al. ${ }^{68}$, and the proline (Pro) content was measured according to Bates et al. ${ }^{69}$. The SOD activity was measured according to Zhang et al. ${ }^{70}$, the POD activity according to Tan et al. ${ }^{71}$, and the CAT activity according to Cakmak and Marschner ${ }^{72}$.

Ionomes. The plant ionomic analysis included the following steps. The leaves, stems, and roots were crushed and passed through sieves. Then, $10 \mathrm{~mL}$ of concentrated nitric acid was added to $100 \mathrm{mg}$ of each sample, which was followed by digestion in a microwave digestion instrument (Milestone, ETHOSA). After microwave digestion, the samples were placed on an electric heating plate at $230^{\circ} \mathrm{C}$ for approximately $20 \mathrm{~min}$ to drive off the acid. After the digestion tank was removed, the solution was transferred to a $25-\mathrm{mL}$ colorimetric tube with ultrapure water. The microwave digestion tank and the lid were rinsed 3 to 5 times to remove all materials. A buffer solution was transferred to the colorimetric tube, diluted to volume, and then shaken evenly. The ion concentrations ( $\mathrm{Na}, \mathrm{P}, \mathrm{K}, \mathrm{Ca}, \mathrm{Mg}, \mathrm{S}, \mathrm{Fe}, \mathrm{B}, \mathrm{Mn}, \mathrm{Zn}, \mathrm{Cu}, \mathrm{Mo}, \mathrm{Ni}, \mathrm{Si}, \mathrm{Co}, \mathrm{Al}$, and $\mathrm{Se}$ ) in leaves, stems, and roots were measured using inductively coupled plasma mass spectrometry (Agilent 7700X ICP-MS, USA).

Gene expression. The expression of GhSOS1 and GhNHX1 was assessed using reverse-transcription quantitative PCR (qRT-PCR).The primers used in the RT-qPCR analysis are listed in Table 2. The qRT-PCR method is given by Peng et al. ${ }^{73}$. The qRT-PCR was performed on an ABI PRISM 7300 Sequence Detection System using $0.1 \mu \mathrm{L}$ of cDNA, $5 \mu \mathrm{L}$ of SYBR Premix Ex Taq II (Takara, Dalian, China), $0.4 \mu \mathrm{L}$ of each primer (forward and reverse, $10 \mu \mathrm{mol} / \mathrm{L}$ ), and $\mathrm{H}_{2} \mathrm{O}$ added to a final reaction volume of $10 \mu \mathrm{L}$. The $\mathrm{qPCR}$ conditions were as follows: preincubation at $95^{\circ} \mathrm{C}$ for $5 \mathrm{~min}$, followed by 40 cycles at $95^{\circ} \mathrm{C}$ for $15 \mathrm{~s}$ and $60^{\circ} \mathrm{C}$ for $1 \mathrm{~min}$. The UBQ7 was chosen as the housekeeping gene for standardizing the qRT-PCR experiments. The relative expression level of each gene was determined relative to UBQ7 as a housekeeping gene and was calculated using the $2^{-\Delta \Delta C T}$ method $^{74}$.

Data analysis. The data were analyzed using SPSS 21.0 software (SPSS Inc., Chicago, IL, USA). Values are presented as the mean $(n=3) \pm$ standard error (SE). Duncan's multiple range tests were conducted to determine whether there were significant differences between individual treatments at $p<0.05$. Pearson's correlation analyses were performed between the concentrations of $\mathrm{Na}$ and those of other minerals in the different tissues $(p<0.05)$. The R package software (Version 4.0.3) was used for principal component analysis (PCA) of the ionome. For hierarchical cluster analysis of the ionomes in cotton plants, the online software was used at MetaboAnalyst website (http://www.metaboanalyst.ca/).

\section{Data availability}

All data generated or analysed during this study are included in this published article (and its Supplementary Information files).

Received: 9 September 2020; Accepted: 3 December 2020

Published online: 14 December 2020

\section{References}

1. Liu, J., Guo, W. Q. \& Shi, D. C. Seed germination, seedling survival, and physiological response of sunflowers under saline and alkaline conditions. Photosynthetica 48(2), 278-286 (2010).

2. Cheng, C. et al. Co-expression of AtNHX1 and TsVP improves the salt tolerance of transgenic cotton and increases seed cotton yield in a saline field. Mol. Breed. 38(2), 19-33 (2018).

3. Ahuja, I., de Vos, R. C., Bones, A. M. \& Hall, R. D. Plant molecular stress responses face climate change. Trends Plant Sci. 15(12), 664-674 (2010).

4. Shi, L., Ma, S., Fang, Y. \& Xu, J. Crucial variations in growth and ion homeostasis of Glycine gracilis seedlings under two types of salt stresses. J. Soil Sci. Plant Nutr. 15(4), 1007-1023 (2015).

5. Munns, R. Comparative physiology of salt and water stress. Plant Cell Environ. 25(2), 239-250 (2002). 
6. Zhang, H. et al. Alkalinity and salinity tolerance during seed germination and early seedling stages of three alfalfa (Medicago sativa L.) cultivars. Legume Res. 40(5), 853-858 (2017).

7. Guo, R. et al. Ionomic and metabolic responses to neutral salt or alkaline salt stresses in maize (Zea mays L.) seedlings. BMC Plant Biol. 17(1), 41 (2017).

8. Javid, M., Ford, R. \& Nicolas, M. E. Tolerance responses of Brassica juncea to salinity, alkalinity and alkaline salinity. Funct. Plant Biol. 39(8), 699-707 (2012).

9. Ahmad, P., Ozturk, M., Sharma, S. \& Gucel, S. Effect of sodium carbonate-induced salinity-alkalinity on some key osmoprotectants, protein profile, antioxidant enzymes, and lipid peroxidation in two mulberry (Morus alba L.) cultivars. J. Plant Interact. 9(1), 460-467 (2014).

10. Hu, L., Zhang, P., Jiang, Y. \& Fu, J. Metabolomic analysis revealed differential adaptation to salinity and alkalinity stress in Kentucky bluegrass (Poa pratensis). Plant Mol. Boil. Rep. 33(1), 56-68 (2015).

11. Wang, N. et al. Physiological salinity tolerance mechanism for transport of $\mathrm{K}^{+}$and $\mathrm{Na}^{+}$ions in cotton (Gossypium hirsutum L.) seedlings under salt stress. Cotton Sci. 27(3), 208-215 (2015).

12. Chachar, Q. I., Solangi, A. G. \& Verhoef, A. Influence of sodium chloride on seed germination and seedling root growth of cotton (Gossypium hirsutum L.). Pak. J. Bot. 40(1), 183 (2008).

13. Belkheiri, O. \& Mulas, M. The effects of salt stress on growth, water relations and ion accumulation in two halophyte Atriplex species. Environ. Exp. Bot. 86, 17-28 (2013).

14. Salt, D. E., Baxter, I. \& Lahner, B. Ionomics and the study of the plant ionome. Annu. Rev. Plant Biol. 59, 709-733 (2008).

15. Parent, S. É. et al. The plant ionome revisited by the nutrient balance concept. Front. Plant Sci. 4, 39 (2013).

16. Wu, D. et al. Ionomic responses and correlations between elements and metabolites under salt stress in wild and cultivated barley. Plant Cell Physiol. 54(12), 1976-1988 (2013).

17. Habib, F., Akram, Z., Akhtar, J., Hussain, S. \& Mansoor, M. Assessment of variations in growth and ionic concentration of salt tolerant and sensitive cotton genotypes. Scientia 3(2), 105-110 (2014).

18. Dai, J. L., Duan, L. S. \& Dong, H. Z. Improved nutrient uptake enhances cotton growth and salinity tolerance in saline media. J. Plant Nutr. 37(8), 1269-1286 (2014).

19. Aleman, $\mathrm{F}$. The Arabidopsis thaliana $H A K 5 \mathrm{~K}^{+}$transporter is required for plant growth and $\mathrm{K}^{+}$acquisition from low $\mathrm{K}^{+}$solutions under saline conditions. Mol. Plant 3(2), 326-333 (2010).

20. Yuan, H. J. et al. $Z x N H X$ controls $\mathrm{Na}^{+}$and $\mathrm{K}^{+}$homeostasis at the whole-plant level in Zygophyllum xanthoxylum through feedback regulation of the expression of genes involved in their transport. Ann. Bot. 115(3), 495-507 (2015).

21. Wu, C. A., Yang, G. D., Meng, Q. W. \& Zheng, C. C. The cotton GhNHX1 gene encoding a novel putative tonoplast $\mathrm{Na}^{+} / \mathrm{H}^{+}$antiporter plays an important role in salt stress. Plant Cell Physiol. 45(5), 600-607 (2004).

22. Endler, A. et al. A mechanism for sustained cellulose synthesis during salt stress. Cell 162(6), 1353-1364 (2015).

23. Gupta, B. \& Huang, B. Mechanism of salinity tolerance in plants: physiological, biochemical, and molecular characterization. Int. J. Genomics 2014, 1-18 (2014).

24. Singh, U. M., Sareen, P., Sengar, R. S. \& Kumar, A. Plant ionomics: a newer approach to study mineral transport and its regulation. Acta Physiol. Plant. 35(9), 2641-2653 (2013).

25. Freitas, V. S., Alencar, N. L. M., de Lacerda, C. F., Prisco, J. T. \& Gomes-Filho, E. Changes in physiological and biochemical indicators associated with salt tolerance in cotton, sorghum and cowpea. Afr. J. Biochem. Res. 5(8), 264-271 (2011).

26. Abbas, G., Saqib, M., Akhtar, J. \& Haq, M. A. U. Interactive effects of salinity and iron deficiency on different rice genotypes. J. Plant Nutr. Soil Sci. 178(2), 306-311 (2015).

27. Wang, N. et al. Relative contribution of $\mathrm{Na}+/ \mathrm{K}+$ homeostasis, photochemical efficiency and antioxidant defense system to differential salt tolerance in cotton (Gossypium hirsutum L.) cultivars. Plant Physiol. Biochem. 119, 121-131 (2017).

28. Lokhande, V. H., Nikam, T. D., Patade, V. Y., Ahire, M. L. \& Suprasanna, P. Effects of optimal and supra-optimal salinity stress on antioxidative defence, osmolytes and in vitro growth responses in Sesuvium portulacastrum L. Plant Cell Tissue Org. 104(1), 41-49 (2011)

29. Bracci, T., Minnocci, A. \& Sebastiani, L. In vitro olive (Olea europaea L.) cvs Frantoio and Moraiolo microshoot tolerance to NaCl. Plant Biosyst. 142(3), 563-571 (2008).

30. Yang, C. et al. Osmotic adjustment and ion balance traits of an alkali resistant halophyte Kochia sieversiana during adaptation to salt and alkali conditions. Plant Soil 294(1-2), 263-276 (2007).

31. Eraslan, F., Inal, A., Savasturk, O. \& Gunes, A. Changes in antioxidative system and membrane damage of lettuce in response to salinity and boron toxicity. Sci. Hortic. 114(1), 5-10 (2007).

32. Koca, H., Bor, M., Özdemir, F. \& Türkan, İ. The effect of salt stress on lipid peroxidation, antioxidative enzymes and proline content of sesame cultivars. Environ. Exp. Bot. 60(3), 344-351 (2007).

33. Pérez-López, U. et al. The oxidative stress caused by salinity in two barley cultivars is mitigated by elevated $\mathrm{CO}_{2}$. Physiol. Plantarum 135(1), 29-42 (2009).

34. Li, Y. Physiological responses of tomato seedlings (Lycopersicon esculentum) to salt stress. Mod. Appl. Sci. 3(3), 171-176 (2009).

35. Mittler, R. Oxidative stress, antioxidants and stress tolerance. Trends Plant Sci. 7(9), 405-410 (2002).

36. Wang, B., Lüttge, U. \& Ratajczak, R. Specific regulation of SOD isoforms by $\mathrm{NaCl}$ and osmotic stress in leaves of the C3 halophyte Suaeda salsa L. J. Plant Physiol. 161(3), 285-293 (2004).

37. Chen, Y., Li, Y., Sun, P., Chen, G. \& Xin, J. Interactive effects of salt and alkali stresses on growth, physiological responses and nutrient (N, P) removal performance of Ruppia maritima. Ecol. Eng. 104, 177-183 (2017).

38. Fan, H., Guo, S., Jiao, Y., Zhang, R. \& Li, J. Effects of exogenous nitric oxide on growth, active oxygen species metabolism, and photosynthetic characteristics in cucumber seedlings under $\mathrm{NaCl}$ stress. Front. Agric. China 1(3), 308-314 (2007).

39. Amirjani, M. R. Effect of salinity stress on growth, mineral composition, proline content, antioxidant enzymes of soybean. Am. J. Plant Physiol. 5(6), 350-360 (2010).

40. Zhang, G., Zhang, L., Chen, B. \& Zhou, Z. Photosynthesis, ion accumulation, antioxidants activities and yield responses of different cotton genotypes to mixed salt stress. Afr. J. Agric. Res. 8(47), 6002-6011 (2013).

41. Ibrahim, W. et al. Comparative physiological analysis in the tolerance to salinity and drought individual and combination in two cotton genotypes with contrasting salt tolerance. Physiol. Plant. 165(2), 155-168 (2019).

42. Lee, G., Carrow, R. N., Duncan, R. R., Eiteman, M. A. \& Rieger, M. W. Synthesis of organic osmolytes and salt tolerance mechanisms in Paspalum vaginatum. Environ. Exp. Bot. 63(1-3), 19-27 (2008).

43. Benzarti, M. et al. Effect of high salinity on Atriplex portulacoides: Growth, leaf water relations and solute accumulation in relation with osmotic adjustment. S. Afr. J. Bot. 95, 70-77 (2014).

44. Azarmi, F., Mozafari, V., Dahaji, P. A. \& Hamidpour, M. Biochemical, physiological and antioxidant enzymatic activity responses of pistachio seedlings treated with plant growth promoting rhizobacteria and Zn to salinity stress. Acta Physiol. Plant. 38(1), 21 (2016).

45. Iqbal, M. N., Rasheed, R., Ashraf, M. Y., Ashraf, M. A. \& Hussain, I. Exogenously applied zinc and copper mitigate salinity effect in maize (Zea mays L.) by improving key physiological and biochemical attributes. Environ. Sci. Pollut. Res. 25(24), 23883-23896 (2018).

46. Kırmız1, S. \& Bell, R. W. Responses of barley to hypoxia and salinity during seed germination, nutrient uptake, and early plant growth in solution culture. J. Plant Nutr. Soil Sci. 175(4), 630-640 (2012). 
47. Kopittke, P. M. Interactions between Ca, Mg, Na and K: Alleviation of toxicity in saline solutions. Plant Soil 352(1-2), 353-362 (2012).

48. Blumwald, E. Sodium transport and salt tolerance in plants. Curr. Opin. Cell Boil. 12(4), 431-434 (2000).

49. Wang, X. P. et al. Physiological responses and adaptive strategies of tomato plants to salt and alkali stresses. Sci. Hortic. 130(1), 248-255 (2011).

50. Shabala, S. et al. Xylem ionic relations and salinity tolerance in barley. Plant J. 61(5), 839-853 (2010).

51. Sanchez, D. H. et al. Comparative ionomics and metabolomics in extremophile and glycophytic Lotus species under salt stress challenge the metabolic pre-adaptation hypothesis. Plant Cell Environ. 34(4), 605-617 (2011).

52. Ali, L., Ashraf, M., Maqbool, M., Ahmad, R. \& Aziz, A. Optimization of soil K:Na ratio for cotton (Gossypium hirsutum L.) nutrition under field conditions. Pak. J. Bot. 45(1), 127-134 (2013).

53. Rodríguez-Navarro, A. Potassium transport in fungi and plants. BBA. Biomembranes 1469(1), 1-30 (2000).

54. Naheed, G., Shahbaz, M., Latif, A. \& Rha, E. S. Alleviation of the adverse effects of salt stress on rice (Oryza sativa L.) by phosphorus applied through rooting medium: Growth and gas exchange characteristics. Pak. J. Bot. 39(3), 729-737 (2007).

55. Wang, J. \& Shuman, L. M. Transformation of phosphate in rice (Oryza sativa L.) rhizosphere and its influence on phosphorus nutrition of rice. J. Plant Nutr. 17(10), 1803-1815 (1994).

56. Hu, Y. \& Schmidhalter, U. Drought and salinity: A comparison of their effects on mineral nutrition of plants. J. Plant Nutr. Soil Sci. 168(4), 541-549 (2005).

57. Dogan, I., Ozyigit, I. I. \& Demir, G. Mineral element distribution of cotton (Gossypium hirsutum L.) seedlings under different salinity levels. Pak. J. Bot. 44, 15-20 (2012).

58. Rabhi, M. et al. Physiological responses of Carthamus tinctorius to $\mathrm{CaCl}_{2}$ salinity under $\mathrm{Mg}$-sufficient and $\mathrm{Mg}$-deficient conditions. Flora 246, 96-101 (2018).

59. Zhang, L. et al. Morphological and physiological responses of cotton (Gossypium hirsutum L.) plants to salinity. PLoS ONE 9(11), e112807 (2014).

60. Severino, L. S. et al. Calcium and magnesium do not alleviate the toxic effect of sodium on the emergence and initial growth of castor, cotton, and safflower. Ind. Crop Prod. 57, 90-97 (2014).

61. Rathert, G. Effects of high salinity stress on mineral and carbohydrate metabolism of two cotton varieties. Plant Soil 73(2), 247-256 (1983).

62. Karimi, G., Ghorbanli, M., Heidari, H., Nejad, R. K. \& Assareh, M. H. The effects of $\mathrm{NaCl}$ on growth, water relations, osmolytes and ion content in Kochia prostrata. Biol. Plantarum 49(2), 301-304 (2005).

63. Tang, J. X., Li, G. L., Xu, X. J. \& Li, Q. L. Effects of $\mathrm{Mn}^{2+}$ and $\mathrm{Mo}^{6+}$ on the salt tolerance of cotton seedling growth. J. Jishou Univ. (Natural Sciences Edition) 27(1), 93-96 (2006).

64. Shi, H., Quintero, F. J., Pardo, J. M. \& Zhu, J. K. The putative plasma membrane $\mathrm{Na}^{+} / \mathrm{H}^{+}$antiporter SOS1 controls long-distance $\mathrm{Na}^{+}$transport in plants. Plant Cell 14(2), 465-477 (2002).

65. Munns, R. \& Tester, M. Mechanisms of salinity tolerance. Annu. Rev. Plant Biol. 59, 651-681 (2008).

66. Ma, Q. et al. ZxSOS1 is essential for long-distance transport and spatial distribution of $\mathrm{Na}^{+}$and $\mathrm{K}^{+}$in the xerophyte Zygophyllum xanthoxylum. Plant Soil 374(1-2), 661-676 (2014).

67. Banjara, M., Zhu, L., Shen, G., Payton, P. \& Zhang, H. Expression of an Arabidopsis sodium/proton antiporter gene (AtNHX1) in peanut to improve salt tolerance. Plant Biotechnol. Rep. 6(1), 59-67 (2012).

68. Wu, H., Wu, X., Li, Z., Duan, L. \& Zhang, M. Physiological evaluation of drought stress tolerance and recovery in cauliflower (Brassica oleracea L.) seedlings treated with methyl jasmonate and coronatine. J. Plant Growth Regul. 31(1), 113-123 (2012).

69. Bates, L. S., Waldren, R. P. \& Teare, I. D. Rapid determination of free proline for water-stress studies. Plant Soil 39(1), 205-207 (1973).

70. Zhang, P., Fu, J. \& Hu, L. Effects of alkali stress on growth, free amino acids andcarbohydrates metabolism in Kentucky bluegrass. Ecotoxicology 21, 1911-1918 (2012).

71. Tan, W. et al. Alterations in photosynthesis and antioxidant enzyme activity in winter wheat subjected to post-anthesis waterlogging. Photosynthetica 46(1), 21-27 (2008).

72. Cakmak, I. \& Marschner, H. Magnesium deficiency and high light intensity enhance activities of superoxide dismutase, ascorbate peroxidase, and glutathione reductase in bean leaves. Plant Physiol. 98(4), 1222-1227 (1992).

73. Peng, Z. et al. Comprehensive analysis of differentially expressed genes and transcriptional regulation induced by salt stress in two contrasting cotton genotypes. BMC Genomics 15(1), 760 (2014).

74. Livak, K. J. \& Schmittgen, T. D. Analysis of relative gene expression data using real-time quantitative PCR and the $2^{-\Delta \Delta C \mathrm{CT}}$ method. Methods 25(4), 402-408 (2001).

\section{Acknowledgements}

This work was jointly funded by The National Natural Science Foundation of China [31660594]. We thank LetPub (http://www.letpub.com) for its linguistic assistance and scientific consultation during the preparation of this manuscript.

\section{Author contributions}

H.G. wrote the main manuscript. H.G., Z.H. and M.L. performed the statistical analysis. H.G. and Z.H. conceived of this study. Z.H. participated in the design and helped to draft the manuscript. All authors read and approved the final manuscript.

\section{Competing interests}

The authors declare no competing interests.

\section{Additional information}

Supplementary Information The online version contains supplementary material available at https://doi. org/10.1038/s41598-020-79045-z.

Correspondence and requests for materials should be addressed to Z.H.

Reprints and permissions information is available at www.nature.com/reprints.

Publisher's note Springer Nature remains neutral with regard to jurisdictional claims in published maps and institutional affiliations. 
(c) (i) Open Access This article is licensed under a Creative Commons Attribution 4.0 International cc) License, which permits use, sharing, adaptation, distribution and reproduction in any medium or format, as long as you give appropriate credit to the original author(s) and the source, provide a link to the Creative Commons licence, and indicate if changes were made. The images or other third party material in this article are included in the article's Creative Commons licence, unless indicated otherwise in a credit line to the material. If material is not included in the article's Creative Commons licence and your intended use is not permitted by statutory regulation or exceeds the permitted use, you will need to obtain permission directly from the copyright holder. To view a copy of this licence, visit http://creativecommons.org/licenses/by/4.0/.

(C) The Author(s) 2020 